\title{
CISTERNA NA STAROM GRADU NOVIGRADU NA DOBRI
}

\section{THE CISTERN AT STARI GRAD NOVIGRAD NA DOBRI}

\author{
Ivana Marinović \\ Stanka Vraza 42D \\ HR - 47000 Karlovac \\ ivanamarinovi66@gmail.com
}

UDK / UDC: $628.13(497.529$ Novigrad na Dobri)"14/15"

Prethodno priopćenje / Preliminary communication

https://doi.org/10.52064/vamz.54.1.28

Stari grad Novigrad na Dobri smješten je u Karlovačkoj županiji, općini Netretić (Zagradci). Zaštićeno je kulturno dobro. Kaštel pripada kasnom srednjem i ranom novome vijeku. Na prostoru kaštela između 2009. i 2012. godine, pod vodstvom Sanjina Mihelića iz Arheološkog muzeja u Zagrebu, provedena su zaštitna arheološka istraživanja unutar kaštela koja su zahvatila prostor sjevernog dijela dvorišta i cisternu. Cisterna pripada filter-tipu, a prema radiokarbonskoj analizi, keramici i odnosu među stratigrafskim jedinicama može se datirati u kraj 15. i početak 16. stoIjeća. Istraženi sustav vodoopskrbe na Starom gradu Novigradu na Dobri sastoji se od cisterne kružnog oblika sa središnjim spremnikom za vodu i filterom, kanala za dovod vode s prostora krovišta kaštela $i$ „kanala-tunela” za regulaciju viškova i dotok vode. Cisterna je smještena u sjeveroistočnom dijelu dvorišta, a svojom je izgradnjom presjekla ranije slojeve ukopavanjem u živu stijenu. Bila je okružena galerijama, od kojih su ostale sačuvane jedino baze kamenih stupaca koje su djelo kasnijih intervencija. Ovaj tip cisterne pojavljuje se početkom razvijenog srednjega vijeka na prostoru srednje Europe i Mediterana, a poradi svoje praktičnosti, nastavlja se koristiti i u ranom novome vijeku na fortifikacijama.

Ključne riječi:

cisterna, filter-tip, Novigrad, Dobra, Frankopani, kaštel, vodoopskrba, novi vijek

Uvod

Stari grad Novigrad na Dobri smješten je na uzvisini (stijeni), na desnoj obali rijeke Dobre, oko 12 km zapadno od Karlovca (karta 1). Istoimeno naselje, zajedno sa starim gradom, pripada Općini Netretić (Zagradci). Lokalitet je danas zaštićeno kulturno dobro (nalazi se na k. č. 1, 5, 9, 20 te dijelovima k. č. 2 i 3, k. o. Zagradci Z-299; karta 2). Na prostoru unutrašnjosti staroga grada zaštitna je arheološka istraživanja proveo Arheološki muzej u Zagrebu
Stari grad Novigrad na Dobri ('the old castle of Newtown (or Newcastle) on the River Dobra') is located in the municipality of Netretić (Zagradci), in Karlovac County. It is protected as a cultural property. The castle belongs to the late medieval and early modern periods. From 2009 to 2012, led by Sanjin Mihelić of the Archaeological Museum in Zagreb, a series of archaeological excavations were carried out in the northern and northwestern parts of the castle yard, including the cistern. The cistern is of filter type; and, on the basis of radiocarbon analysis, found ceramics, and relations between stratigraphic units, it can be placed chronologically at the end of the $15^{\text {th }}$ century or the beginning of the $16^{\text {th }}$. The researched water supply system at Stari grad Novigrad na Dobri consists of a circularly-shaped cistern with its central tank and filter, channels for draining water from the castle's roofing, and a tunnel/channel designed for regulation of excess water. The cistern is located in the northeastern part of the castle yard, where it was dug into the bedrock. It was surrounded by galleries, of which only the bases of the later-built stone columns have been preserved. This cistern type appeared at the beginning of the high medieval period in Central Europe and the Mediterranean, and because of its characteristics, this type continued to be used on fortifications in the early modern period.

Key words:

cistern, filter-type, Novigrad, River Dobra, Frankopan, castle, water management, early modern period

\section{Introduction}

Stari grad Novigrad na Dobri is located on a hill on the right bank of the River Dobra, about $12 \mathrm{~km}$ west of Karlovac (Map 1). The village of the same name, together with the castle, belongs to the municipality of Netretić (Zagradci). The site is now a protected cultural property (on cadastral parcels $1,5,9,20$ and parts of 2 and 3, c. p. Zagradci Z-299; Map 2). From 2009 to 2012, a series of protective archaeological excavations were carried out within 
KARTA 1. Položaj Staroga grada Novigrada na Dobri na karti Hrvatske (OGoogleMaps).

MAP 1. Position of Stari grad Novigrad na Dobri on a map of Croatia (@GoogleMaps).

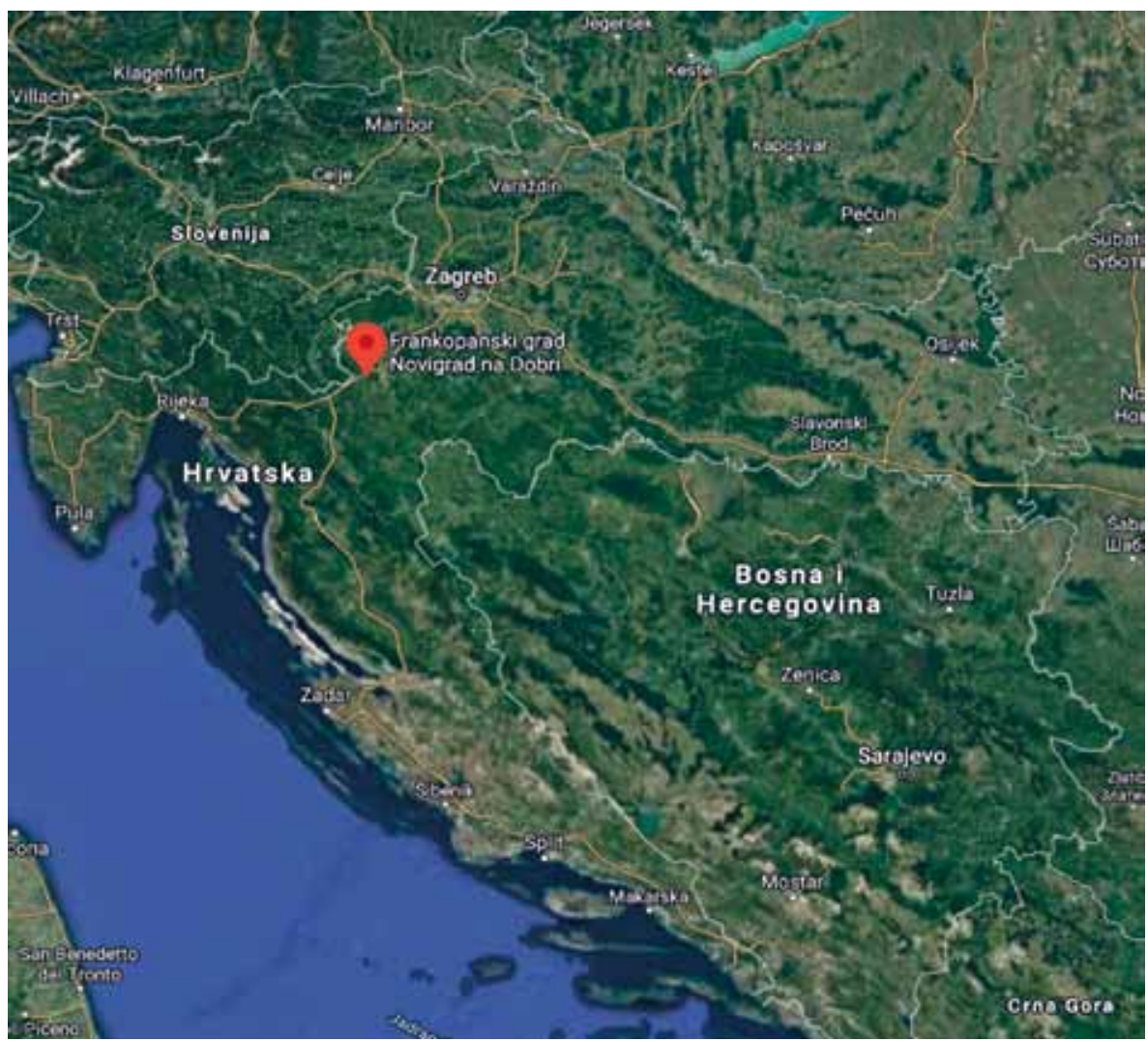

pod vodstvom Sanjina Mihelića od 21. listopada do 30. studenoga 2009., od 9. lipnja do 16. rujna 2010., od 8. kolovoza do 6. rujna 2011. i od 26. lipnja do 4. kolovoza 2012. godine. Istraživanja su obuhvatila prostor unutarnjeg dvorišta i cisterne, a njima je ustanovljeno okvirno vrijeme izgradnje kaštela i začetka ljudske djelatnosti u njemu, ali i postojanje organiziranog sustava vodoopskrbe. U ovom je radu riječ upravo o potonjoj arhitektonskoj komponenti Staroga grada Novigrada na Dobri, u središtu koje se nalazi cisterna. Cilj je rada na primjeru novigradske cisterne prezentirati izgled i princip rada filter-tipa cisterne, objasniti položaj cisterne unutar kaštela te pritom predstaviti njezinu tipologiju, ali i nazivlje njezinih arhitektonskih dijelova pa na taj način doprinijeti daljnjim istraživanjima i razumijevanju teme vodoopskrbe na srednjo-i novovjekovnim fortifikacijama.

\section{Povijesni pregled kaštela Stari grad Novigrad na Dobri}

Stari grad Novigrad na Dobri povezuje se s toponimom Dobra i nazivom Dobrenin u drugoj polovini 13. stoljeća Također, u povijesnim izvorima navodi se kako je na prostoru oko rijeke Dobre živjelo pleme Dobransko (u listinama se spominju plemići Dobranski). ${ }^{1}$ Toponim Novigrad na Dobri (Novi grad) u povijesnim izvorima pojavljuje se krajem 15. stoljeća (najstarija isprava koja govori o Novom gradu je iz 1495. godine), a veže se uz obitelj Frankopan, i to posebno uz Bernardina Frankopana i njegova unuka Stjepana Ozaljskog, iz čijeg vremena potječe i najviše isprava the castle, initiated by the Archaeological Museum in Zagreb and led by Sanjin Mihelić. The excavations covered part of the castle yard, including the cistern, and their results helped determine the dating of the castle's construction and its residents' activity, but they also revealed the existence of the former water management system in the castle, which is the main subject of this paper. With the cistern at Novigrad na Dobri as an example, the appearance, location within the castle, and main work principle of the filter-type cistern will be introduced, as well as its typology and terminology, with the intention of contributing to the research of water-supply management at fortifications in the medieval and early-modern periods.

\section{History of Stari grad Novigrad na Dobri Castle}

'Stari grad Novigrad na Dobri' is related to the toponym 'Dobra' and the name 'Dobrenin', which appeared in the second half of the $13^{\text {th }}$ century. In historical sources, it is mentioned that a tribe called the Dobransko resided by the River Dobra (sources mentioning the noblemen of Dobra). ${ }^{1}$ The toponym 'Novigrad na Dobri' (Novi grad) first appeared at the end of the $15^{\text {th }}$ century (the oldest document about Novi grad being dated 1495) and was linked with the Frankopan family, especially with Bernardin Frankopan and his grandson Stjepan of Ozalj, in whose period 


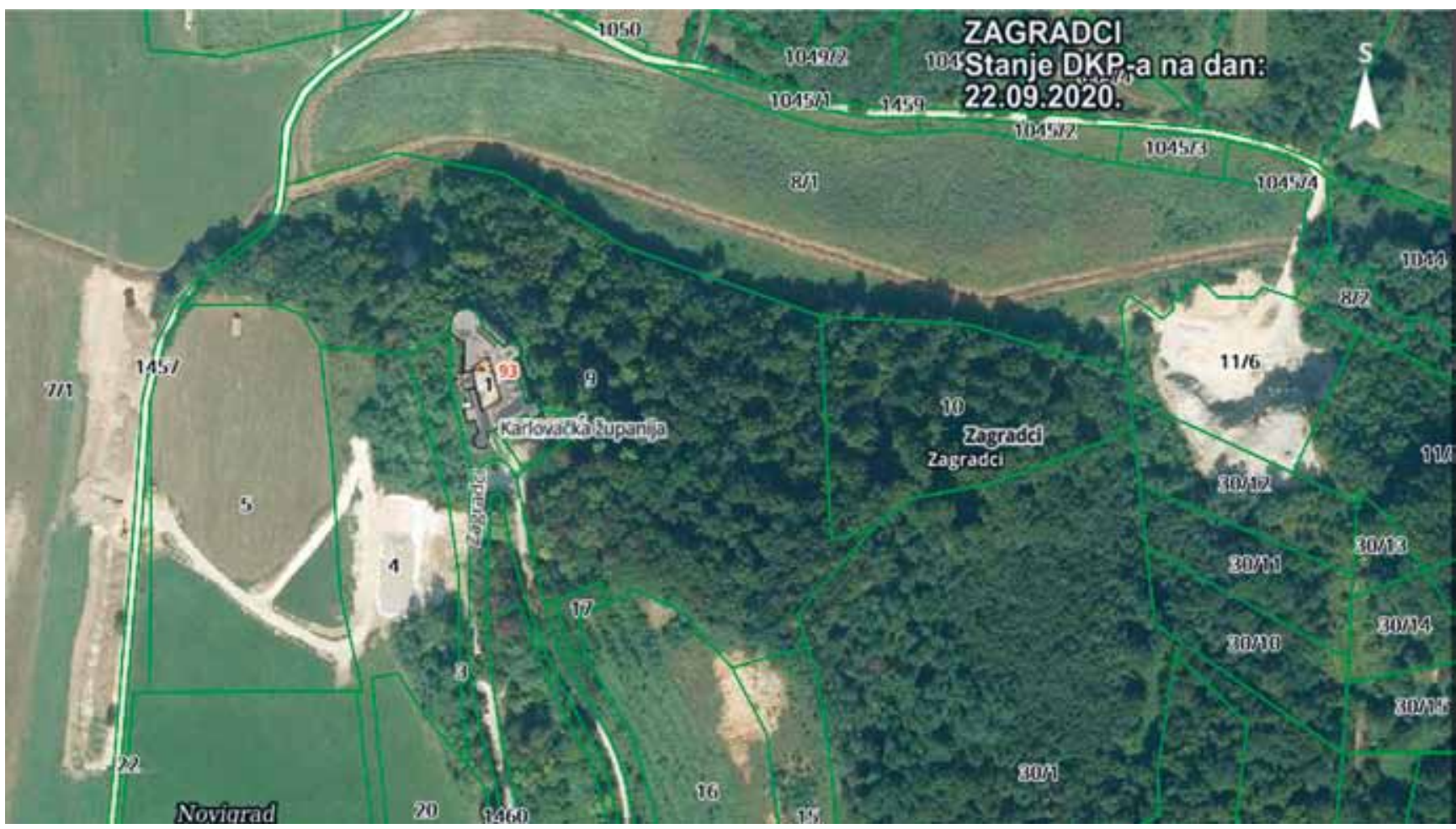

KARTA 2. Položaj Staroga grada Novigrada na Dobri (@Geoportal).

o Novigradu na Dobri. ${ }^{2}$ Dvorac su 1543. godine napali i zapalili Osmanlije, nakon čega je obnavljan za Vuka Krste Frankopana početkom 17. stoljeća. Novigrad je bio u vlasništvu obitelji Frankopan do izbijanja i gušenja Zrinsko-Frankopanske urote 1667. 1671. godine, nakon čega je imovina Zrinskih i Frankopana oduzeta i razdijeljena. Dvorac je postao dobrom karlovačkog generala grofa Johanna Josepha Herbersteina 1676. godine, koji ga nakon smrti 1689. godine ostavlja Malteškom viteškome redu. Malteški red, za čijeg vremena dvorac nije održavan, prodaje ga 1746. godine barunu Stjepanu Patačiću, koji ga preuređuje u baroknom stilu. Zanimljivo je da je u vrijeme Patačića u dvorcu boravio car Josip II., a povodom toga događaja barunica Katarina Patačić je iznad ulaznih vrata u dvorac podignula natpisnu ploču. ${ }^{3}$ Patačići dvorac prodaju u vrijeme francuske okupacije (1809. godine) Mirku Haraminčiću, od čijih je potomaka dvorac otkupio Zemaljski erar. Od Zemaljskog erara na javnoj dražbi dvorac je otkupio karlovački veletrgovac Franjo pl. Türk, koji ga je popravio i uredio u duhu kraja 19. stoljeća. ${ }^{4}$ Nakon obitelji Türk vlasnik je dvorca barun Zdenko Turković, koji posjed prodaje Banovini Hrvatskoj. U Drugome svjetskom ratu, između 6. i 7. siječnja 1944. godine, dvorac je zapaljen. ${ }^{5}$
MAP 2. Position of Stari grad Novigrad na Dobri (๔Geoportal).

the largest number of documents about the castle originate. ${ }^{2}$ In 1543 the castle was attacked and burned by the Ottomans. It was rebuilt in the period of Vuk Krsto Frankopan at the beginning of the $17^{\text {th }}$ century. The Frankopan family stayed in possession of Novigrad na Dobri until their downfall after the ZrinskiFrankopan Conspiracy (1667 - 1671), which led to confiscation and division of their property. In 1676 the castle came into the possession of Johann Joseph Herberstein, a general from Karlovac, who left it, after his death in 1689, to the Knights of Malta. In this period it was not maintained until the year 1746, when it was sold to Baron Stjepan Patačić, who renovated it in the Baroque style. It is interesting to mention that, during the period of Patačić's possession, the emperor Joseph II stayed in the castle. This visit was documented on the panel placed above the castle's entrance, erected by Baroness Katarina Patačić. ${ }^{3}$ The Patačić family sold the castle to Mirko Haraminčić during the French occupation (1809), after whose death it was bought by the state treasury. The state sold it at auction to Franjo Türk, a merchant from Karlovac, who renovated it in a style typical of the end of the $19^{\text {th }}$ century. ${ }^{4}$ After the Türk family, the castle came into the possession of Zdenko Turković, who sold it to the Banovina of Croatia. During World War Two, on the $6-7^{\text {th }}$ of January 1944, the castle was burned. ${ }^{5}$
Lopašić 1895, 185

Sekulić-Gvozdanović 1966.

Lopašić 1895, 192.

Kruhek 2003.
Lopašić 1895, 185

Sekulić-Gvozdanović 1966.

Lopašić 1895, 192

Kruhek 2003. 


\section{Polazišna razmatranja i stanje istraženosti}

Istraživanje sustava vodoopskrbe na fortifikacijama (visinskih i nizinskih, obrambenog i stambenog karaktera) predstavlja zanimljivu temu u sklopu arheoloških istraživanja burgova i kaštela, a ponajviše jer donose saznanja o organiziranim načinima vodoopskrbe u srednjem i ranom novome vijeku. Na tu temu pojavIjuju se na prostoru srednje i zapadne Europe brojni radovi koji obrađuju cisterne na nalazištima u Njemačkoj (Münzenberg, ${ }^{6} \mathrm{Ho}$ henburg pokraj Homberga u Hessenu, 7 Burg Hessonen u Wolfsöldenu, ${ }^{8}$ Burg Kirkel), Austriji (Friedberg u dolini rijeke Inn, Thierberg, Innsbruck, Lockenhaus u Burgenlandu (Gradišću), Zeiselberg u Koruškoj), Švicarskoj (Alt Wartburg, Frohburg u kantonu Solothurn, Schiedberg u kantonu Graubünden), ${ }^{9}$ na sjeveru Italije (južni Tirol; primjerice, Burg Prösels u južnom Tirolu, Hocheppan, Rodengo, Reifenstein u Sterzingu), Belgiji (La Roche en Ardene), Sloveniji (Stari grad Celje), ${ }^{10}$ jugoistočnoj Europi (Tarnovgrad u Bugarskoj) i Bliskom istoku (Crac des Chevaliers). ${ }^{11}$ Posebno se izdvajaju radovi Suzane Arnold, Urlicha G. Großmanna i Stefanie Juch, koji donose podatke o cjelovito istraženim cisternama i koji mogu poslužiti kao presedan za pristup istraživanju ove teme. Pomoću navoda autora moguće je ustanoviti uvriježeni obrazac „rada“ filter-tipa cisterni i opisati njezine sastavne dijelove. Ovaj tip sastoji se od dva glavna dijela: središnjeg spremnika za vodu (njem. Schöpfschacht, engl. reservoir, tank), koji može biti kameni ili drveni i čija dubina varira, te prostora filtera koji se u pravilu sastoji od nasipanog šljunka, pijeska, riječnih oblutaka, šodera, gline i ilovače, i koji je zatvoren zidom cisterne. Vanjski je zid (zid cisterne) bio izgrađen od kamena i povezan žbukom, a obično je s vanjske strane bio obložen debelim slojem gline ili hidraulične žbuke koja je sprječavala otjecanje zahvaćene vode smještene u prostoru filtera. Ovaj tip cisterne radi na principu dovođenja voda s prostora krovišta putem kanala (podzemnih i nadzemnih) kroz vanjski zid u filter, gdje se voda pročišćava i odakle prodire u središnji spremnik. Voda s prostora krovišta ponekad se dovodi izravno u središnji spremnik za vodu. U slučaju da je cisterna smještena u dvorištu, filter bi se punio vodom zahvaćenom s prostora dvorišta (putem drenaže, tj. taraca). ${ }^{12}$ Važno je napomenuti da je filter-cisterna izgledom često vrlo slična bunaru, zbog čega se mnogi primjerci cisterni pogrešno nazivaju bunarima. ${ }^{13}$ Istraženost srednjo- i ranonovovjekovnih cisterni na prostoru Hrvatske, posebno onih izgrađenih u sklopu fortifikacija, prilično je skromna. Bavljenje temom vodoopskrbe također je tek u povojima, a među prvim autorima koji su se ozbiljnije njome bavili svakako valja istaknuti Tatjanu Tkalčec i Zorislava Horvata. Tatjana Tkalčec je objavila rezultate istraživanja cisterne na Burgu Vrbovec u Klenovcu Humskom (Hum na Sutli) te time dala uvid

\section{Initial reflections and state of research}

The research and study of water supply and water management at defensive and residential fortifications (castles and burgs, lowland and highland) is a very interesting subject of archaeological research, mostly because it can expand the understanding of water management in medieval and early-modern times. Various papers on this topic have appeared in central and western Europe, some of which describe the cisterns at archaeological sites in Germany (Frankenberg in Mittelfranken, Münzenberg, ${ }^{6}$ Hochenburg near Homberg in Hessen,7 Burg Hessonen in Wolfsölden, ${ }^{8}$ Burg Kirkel), Austria (Friedberg in Inntal, Thierberg, Innsbruck, Lockenhaus in Burgenland, Zeiselberg in Kärnten), Switzerland (Alt Wartburg, Frohburg in the Solothurn canton, Schiedberg in the Graubünden canton), ${ }^{9}$ the north of Italy (South Tirol, for example, Burg Prösel; , Hocheppan, Rodengo, Reifenstein in Sterzing), Belgium (La Roche-en-Ardenne), Slovenia (Castle of Celje), ${ }^{10}$ southeast Europe (Tarnovgrad, in Bulgaria) and the Middle East (Crac des Chevaliers). ${ }^{11}$ Papers written by Susanne Arnold, Ulrich G. Großmann and Stefanie Juch, are in particular very valuable as a source of information on this subject. On the basis of these works, the main principles and characteristics of a well-filtered cistern (filter-type) can be determined, and the main parts of the cistern described. It consists of two main parts: a central water tank (Ger. Schöpfschacht) made out of stone or wood and of varying depth, and a filter made of gravel, sand, pebbles, clay and loam. The cistern wall was often lined on the outside with a layer of clay or hydraulic lime, which prevented the outflow of water from the filter. This cistern type uses a system of channels for bringing the rainwater from the castle's roofing through the outer wall into the filter, out of which it enters the central tank as water suitable for drinking and general usage. In some cases, water was brought directly to the central tank. If the cistern was positioned in the castle yard, water would have been brought in from the surrounding yard. ${ }^{12}$ Because of some of its architectural characteristics and general appearance, a filtertype cistern is often mistaken for a simple water-well. ${ }^{13}$ Because of this, in some works the term 'well' is used in reference to the central tank of the cistern. Research into cisterns is crucial for general understanding and further studies of water supply systems and water management at medieval and early-modern fortifications. Research on cisterns at fortifications located in the continental part of Croatia is still at its beginning. Detailed problematization of water-management topics in Croatian archaeological literature is modest, as well. However, there are several essential works written by Tatjana Tkalčec and Zorislav Horvat. Archaeological research on Burg Vrbovec (Hum na Sutli)

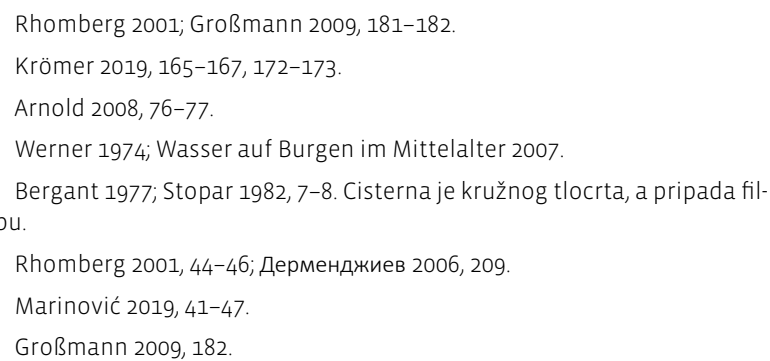

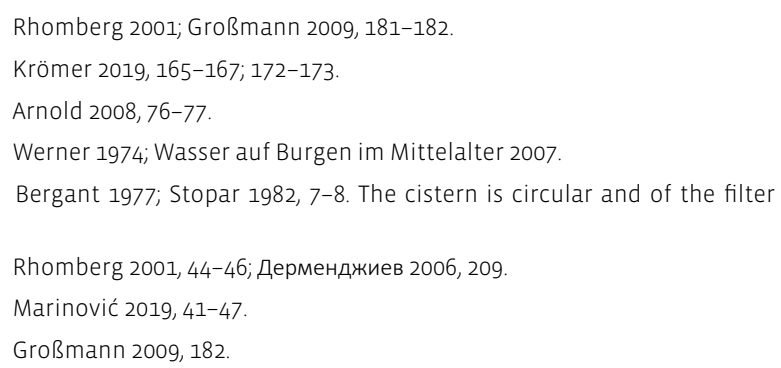




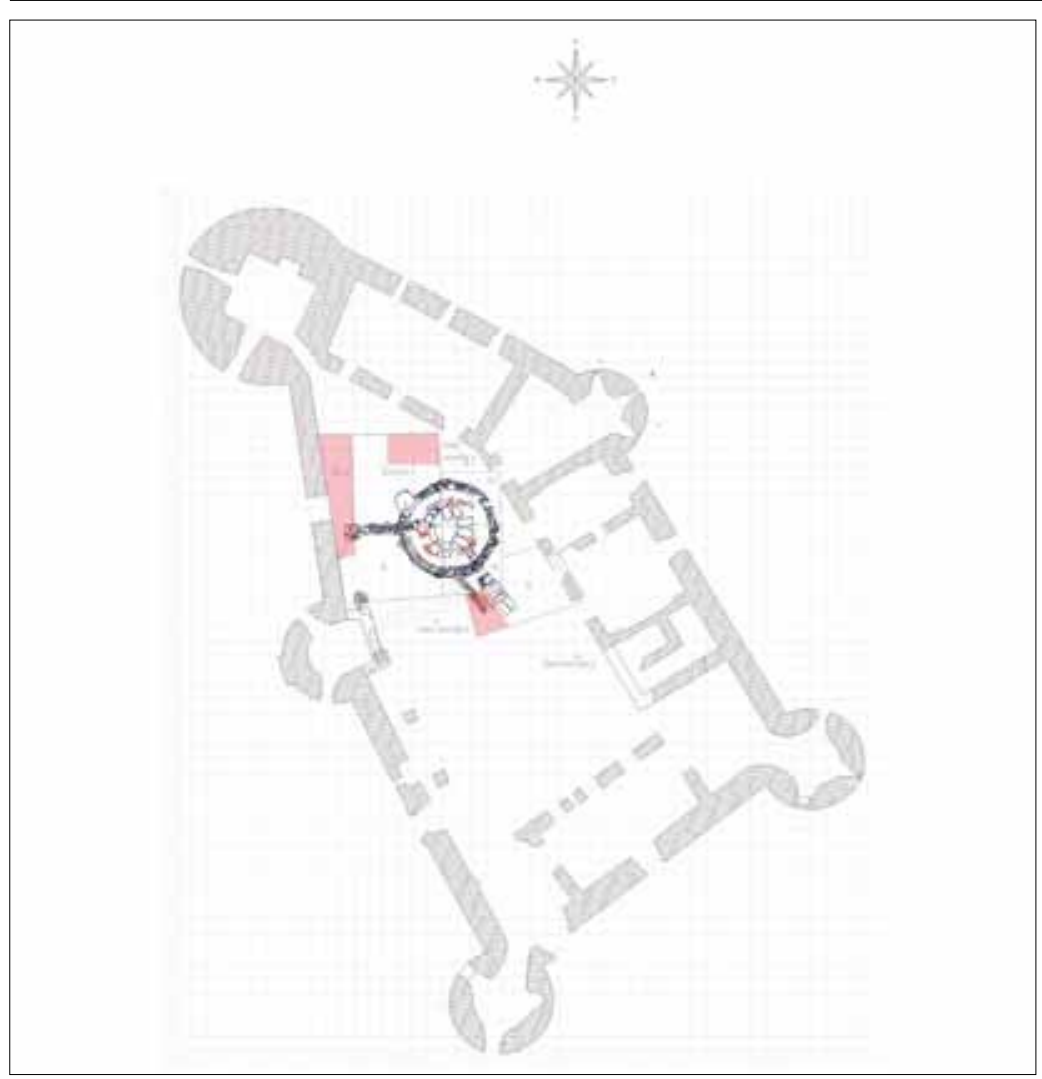

SLIKA 1. Tlocrt Staroga grada Novigrada na Dobri s označenom cisternom (izradila N. Šegvić). FIGURE 1. Plan of Stari grad Novigrad na Dobri with marked cistern (made by $\mathrm{N}$. Šegvić).

u izgled jedne takve građevine na burgu s prostora kontinentalne Hrvatske. ${ }^{14}$ Premda cisterna na Burgu Vrbovec nije istražena do kraja (do zdravice), objavljeni rezultati pokazuju postojanje organiziranog sustava vodoopskrbe, ali i moguće korištenje filter-tipa u 13. stoljeću. ${ }^{15}$ Cisterna je ukopana u živu stijenu, koja je prema vanjskom zidu erodirala, što je naposljetku dovelo do istjecanja njezina sadržaja. To je ujedno uzrokovalo i njeno napuštanje i zapunjavanje keramičkim materijalom kroz 15. i 16. stoljeće. ${ }^{16} \mathrm{Uz}$ Tkalčec, temu je cisterni dotaknuo i Zorislav Horvat, koji je naveo tipove, ali i nalazišta na kojima se nalaze pojedine cisterne: Medvedgrad, Garić, Dobra Kuća, Novi Vinodolski, Okić, Zelingrad, Komić u Lici i Ozalj. ${ }^{17}$ Između navedenih posebno se izdvaja cisterna sa Zelingrada, koja je bila načinjena od kružno postavljenih, precizno klesanih kamenih blokova koji su sezali do dubine oko 4,5 m, ispod čega se nalazio sloj ilovače. ${ }^{18}$ Navedeni primjeri predstavljaju tek početak istraživanja i objavljivanja problematike cisterni. Daljnjim istraživanjima i problematizacijom teme vodoopskrbe na fortifikacijama moći će se više reći o njihovoj izgradnji, tipologiji i ostalim važnim podacima koji mogu oplemeniti ovo područje istraživanja. by Tatjana Tkalčec is significant in topics of water supply in latemedieval castles in the continental part of Croatia. ${ }^{14}$ The medieval cistern at Burg Vrbovec was set in the yard and was dug into the bedrock. There are assumptions that this cistern might be a well-filtered cistern, and according to research results it can be dated to the $13^{\text {th }}$ century. ${ }^{15}$ The cistern was damaged by stone erosion and, after that, was filled with pottery waste through the $15^{\text {th }}$ and $16^{\text {th }}$ century. ${ }^{16}$ Another important work concerning cistern types on continental archaeological sites - the castles of Medvedgrad, Garić, Dobra Kuća, Novi Vinodolski, Okić, Zelingrad, Komić in Lika, and Ozalj - has been written by Zorislav Horvat. ${ }^{17}$ Among the above examples, one interesting case is the cistern at Zelingrad castle, made of circularly stacked stone blocks. The stone construction reached about $4.5 \mathrm{~m}$ in depth, below which was a layer of loam. ${ }^{18}$ Through subsequent research, various examples of found cisterns would be further contextualized through analogies relating to their construction, typology and other determining characteristics. The main aim of this article is to describe, using the example of the cistern at Novigrad na Dobri, the filter-type cistern and determine its position in the castle yard, as well as explain how it functioned as a part of the castle's water supply system. That being said, this article strives to contribute to further research in this historical and archaeological topic of interest.

\footnotetext{
4 Tkalčec 2019, 145.

Tkalčec 2010a, 32-33.

Tkalčec 2010a, 32; 2019, 146-150

Horvat 2012, 10-11.

Houška, Mačković 2009, 56-57.
}

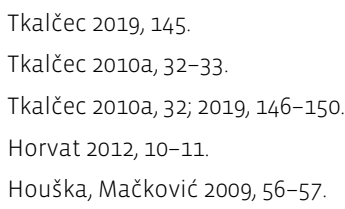




\section{Smještaj i izgled cisterne unutar ranonovovjekovnog kaštela}

Cisterna na Starom gradu Novigradu na Dobri nalazi se u sjeveroistočnom dijelu dvorišta (sl. 1) ${ }^{19}$ te tako smještena dijeli prostor između sjeverne kule i jugoistočnog dijela kaštela (sl. 2).

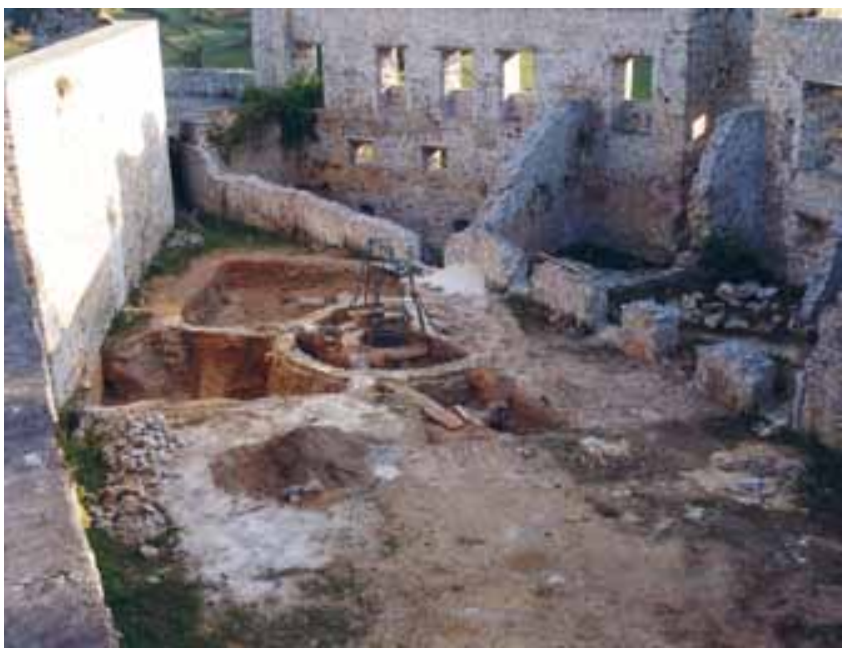

SLIKA 2. Položaj cisterne unutar kaštela (Arhiv terenske dokumentacije Novigrad na Dobri).

FIGURE 2. Position of the cistern within the castle (Excavation documentation archives, Novigrad na Dobri)

Ukopana je u živu stijenu (SJ 153), a svojim ukopom (SJ 151) presjekla je ranije slojeve (SJ 070, 072, 022, 084). Kružnoga je oblika, a sastoji se od dva koncentrična kruga. Vanjski kružni zid (zid cisterne, SJ 006) dijeli filter od okolnog prostora dvorišta, a udaIjen je $180 \mathrm{~cm}$ od središnjeg spremnika za vodu. ${ }^{20}$ Bio je načinjen od nepravilnog poluobrađenog i lomljenog kamenja, slaganog i povezivanog žbukom, a s vanjske je strane obložen debelim nanosom gline koji je priječio istjecanje vode iz filtera (sl. 3). Neposredno uz vanjski zid nalazila se zapuna ukopa (SJ 151) koju su činili pijesak i žućkasta glina (SJ 061), a na nekim mjestima žutonarančasta glina (S) 032 u sjevernom djelu sektora I i na prostoru sektora II SJ 042, 057, 058, 059 i SJ 008), koja je popunila prostor neposredno uz cisternu. ${ }^{21}$

Nasipavanjem i poravnavanjem omogućena je stabilnost same građevine (cisterne) i ravan izgled hodne površine unutar dvorišta kaštela. Prostor između vanjskog zida cisterne i središnjeg

\section{Appearance and position of the cistern within an early-modern castle}

The cistern at Stari grad Novigrad na Dobri was set in the northeast part of the yard (Fig. 1). ${ }^{19}$ The cistern divides the space between the northern tower and the southeastern parts of the castle (Fig. 2).

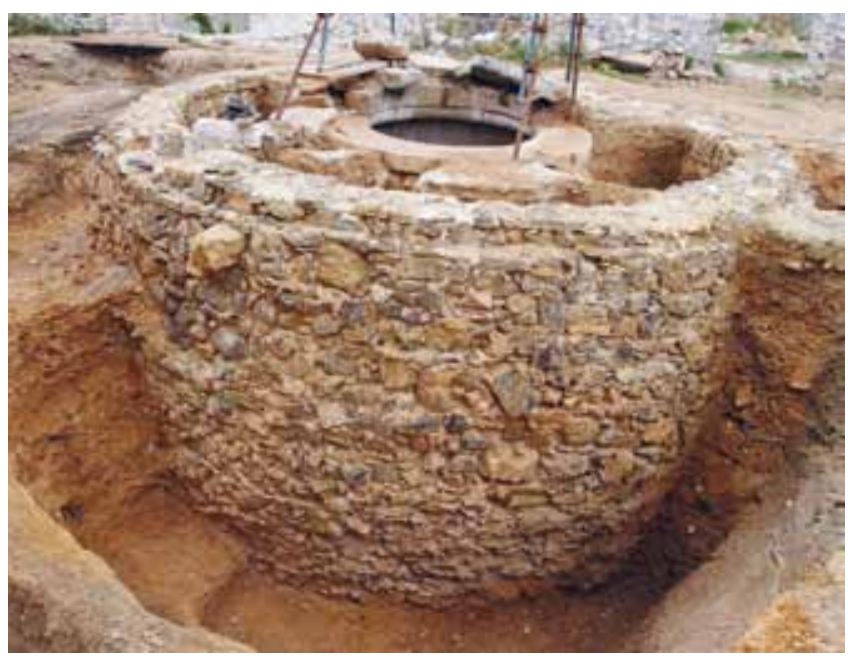

SLIKA 3. Vanjski zid cisterne (sektor II; Arhiv terenske dokumentacije Novigrad na Dobri).

FIGURE 3. Outer cistern wall (sector II; Excavation documentation archives, Novigrad na Dobri).

It was dug into the bedrock (stratigraphic unit SU 153), and during its construction former layers (SU 070, 072, 022, 084) were intersected (SU 151). The cistern is cylindrical and consists of two concentric walls (wall of the cistern SU 006). The outer wall, set about $180 \mathrm{~cm}$ from the central water tank, separates the filter from the surrounding yard space..$^{20}$ It was made of masonry, of irregular and broken stones bound with a thick layer of hydraulic lime and lined with a thick layer of clay. This was common practice for preventing water outflow (Fig. 3). On the outer side of the cistern wall there was an impermeable layer (SU 151) of consistent filling made of sand and yellowish and red clay (SU 061); this situation is present in sectors I and II, in stratigraphic units 032, $042,057,058,059$ and $008 .{ }^{21}$

Levelling of the ground surrounding the cistern was done to seal its construction under the ground and to even out the walking space, allowing access to the cistern. The space between the
19 Podaci koji su korišteni prilikom pisanja ovoga rada preuzeti su iz dokumentacije Arheološkog muzeja u Zagrebu vezane uz istraživanja Staroga grada Novigrada na Dobri 2009. - 2012. godine, koja su provedena pod vodstvom Sanjina Mihelića, uz sudjelovanje Ive Kostešić i Nere Šegvić, u suradnji s Konzervatorskim odjelom u Karlovcu. Korištenu je dokumentaciju ustupio Arheološki muzej u Zagrebu, odnosno voditelj istraživanja Sanjin Mihelić

20 Mihelić 2010, 310-313

21 Mihelić 2013; Juch 2016, 29-30
19 Data used for writing this article has been drawn from the documentation containing excavation records for Stari grad Novigrad na Dobri (2009 to 2012), which is kept in the Archaeological Museum in Zagreb. The excavations were initiated by the Archaeological Museum in Zagreb and led by Sanjin Mihelić, Iva Kostešić and Nera Šegvić in cooperation with the Conservation Department in Karlovac. The documentation was provided by Sanjin Mihelić at the author's request.

\footnotetext{
20 Mihelić 2010, 310-313.

21 Mihelić 2013; Juch 2016, 29-30.
} 
spremnika za vodu bio je ispunjen filterom (SJ 060, 049; koji presijeca SJ 003, devastirani sloj sačinjen od opeke i kamena; sl. 4).22 Istraženi dio filtera sastojao se od žućkasto-narančaste pjeskovite zemlje, pijeska i tragova gline.

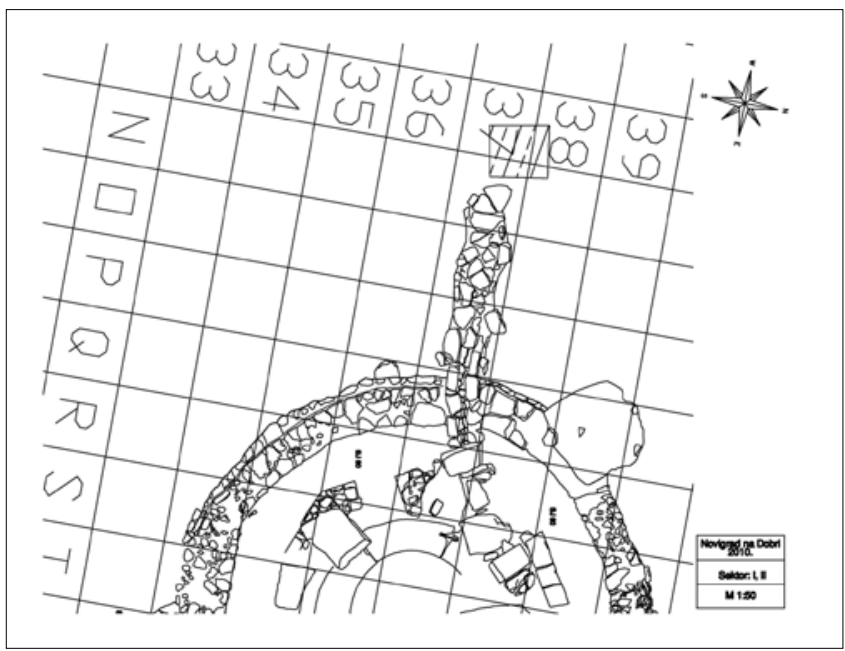

SLIKA 4. Prostor filtera (SJ 060; izradila N. Šegvić). FIGURE 4. Filter (SU 060; made by N. Šegvić).

Poznat nam je jedino njegov površinski dio koji se odnosi na SJ 060 i $049 .{ }^{23}$ Središnji je spremnik bio kružnog oblika (SJ 005 (004)), promjera $170 \mathrm{~cm}$ (sl. 5), načinjen od pravilno tesanih kamenih blokova koji su kružno slagani jedan na drugi i na nekim mjestima pažljivo povezivani žbukom. ${ }^{24}$ Gornji je vijenac cisterne bio povezan željeznim zategama. Okruživalo ga je oktogonalno popločanje od opeka (SJ 024) neposredno uz zapadni i jugozapadni dio. $\mathrm{Na}$ vijenac, i dijelom na oktogonalno popločanje, nalijegale su kamene ploče trapezoidnoga oblika duljine $135 \mathrm{~cm}$, slagane jedna pokraj druge. Na tim trapezoidnim pločama nalazila se kruna cisterne kružnoga oblika.

Izgled je krune poznat s fotografije Staroga grada Novigrada na Dobri iz razdoblja koje je prethodilo njegovu razaranju u Drugome svjetskom ratu (sl. 6). Središnji spremnik za vodu nije istražen do kraja (zapuna je spremnika označena kao SJ 050). Prilikom istraživanja postignuta je dubina od $3 \mathrm{~m} .{ }^{25}$ outer wall and central tank was filled with a layer of filter (Fig 4; SU 060, 049; this was intersected by SU 003, a devastated layer made of brick and stone fragments) made of small mixed stones, fragments of clay, pebbles and sediment.22 The colour of this sediment was orange and ochre. The filter was not completely excavated and researched, which is why its complete structure remains unknown.

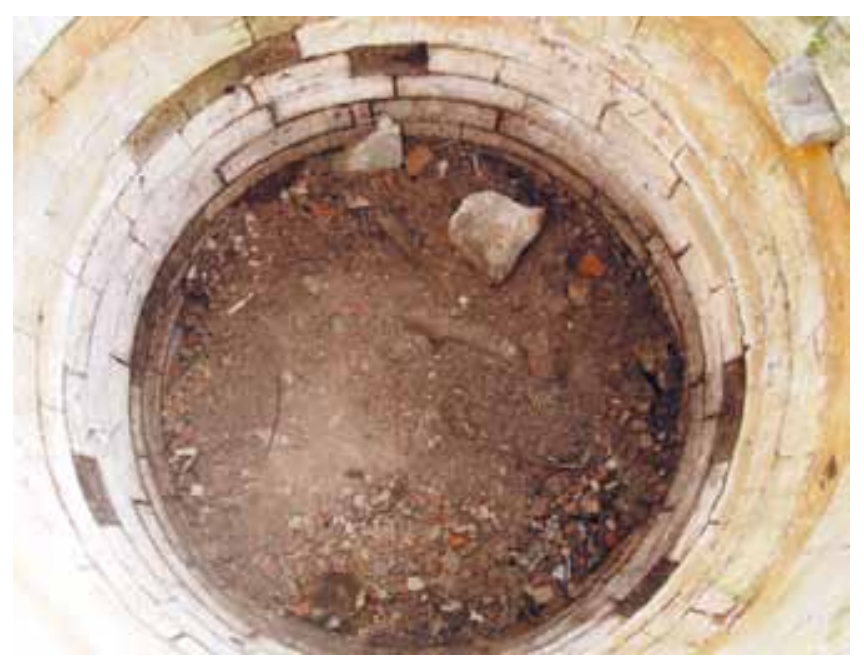

SLIKA 5. Središnji spremnik za vodu (SJ 005 (004); Arhiv terenske dokumentacije Novigrad na Dobri).

FIGURE 5. Cistern's central water tank (SU 005 (004); Excavation documentation archives, Novigrad na Dobri).

The researched part only consists of the two surface layers marked as SU 060 and $049 .{ }^{23}$ The central water tank (Ger Schöpfschacht) was circularly shaped (SU 005 (004)), $170 \mathrm{~cm}$ in diameter (Fig. 5). It was made from finely carved stone blocks, in some places carefully sealed with lime or mortar. ${ }^{24}$ The central tank's upper part had a cornice reinforced with iron strainers, which was originally set on the octagonal brick paving. Parts of the cornice and octagonal brick paving (structure) were sealed with massive stone slabs, approximately $135 \mathrm{~cm}$ long, set around the central tank.

The cistern's crown is visible in the photograph taken before the abovementioned destruction of the castle in the Second World War (Fig. 6). It is important to mention that the central water tank was not fully researched, either (The central water tank filling is marked as SU 050). The depth reached during the excavations was $3 \mathrm{~m}^{25}$

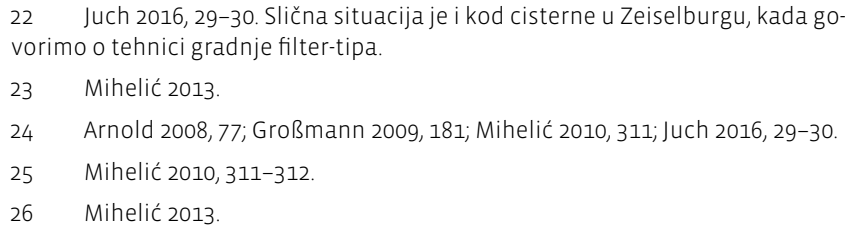


Slika 6. Fotografija krune cisterne iz 40-ih godina 20. stoljeća (HR-DAKA-0147).

FIGURE 6. Photograph of the cistern's crown from the 1940 S (HR-DAKA-0147).

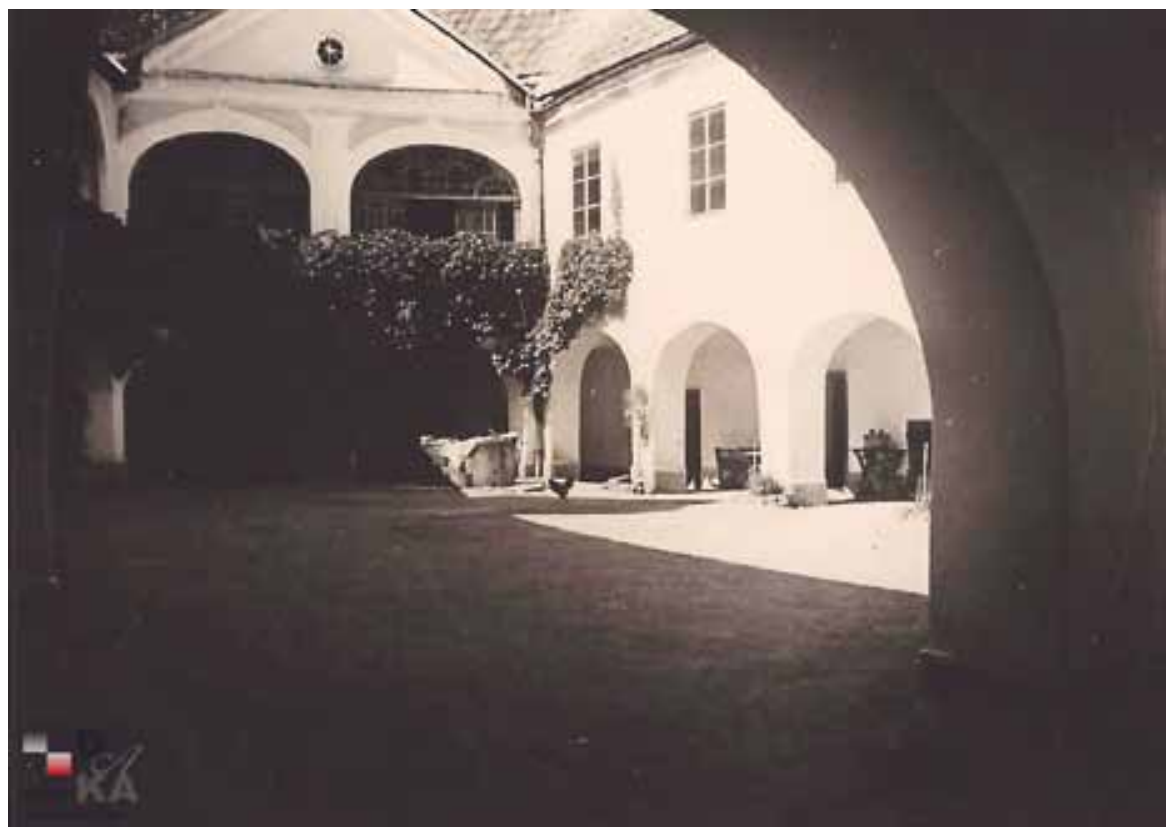

Možda je cisterna, slično kao na Medvedgradu, bila ograđena kamenim zidićem, na što ukazuje završetak zida (SJ 006) koji se prema hodnoj površini malo uvlači. Novigradska je cisterna najvjerojatnije sagrađena krajem 15. ili početkom 16. stoljeća, u vrijeme Stjepana II. (III.) Modruškog i njegova sina Bernardina Frankopana prilikom prve faze preuređenja srednjovjekovnog burga (Dobre) u ranorenesansni kaštel. Na to ukazuju tragovi graditeljske aktivnosti iz toga doba, a to podupire i činjenica da su u vrijeme Bernardina Frankopana mnogi frankopanski dvorci bili obnovljeni i dograđivani.

\section{Organizacija prostora oko cisterne}

Novigradska cisterna slijedi pravila i način izgradnje filter-tipa, ukopana je u stijenu i smještena u dvorištu kaštela, na položaju pokraj najvećeg prostora krovišta putem kojega se punila. Krovište je možda bilo načinjeno od glinenoga crijepa, na što ukazuje nalaz ulomka keramičke ploče (crijepa) u SJ 167 (sektor VI-1), ciglaste boje, debljine $2 \mathrm{~cm} .{ }^{26}$ Također, o postojanju krovišta na tome dijelu i gornjim dijelovima kaštela govore nalazi kamenih stupaca. Položaj kamenih stupaca u odnosu na cisternu pokazao se važnim u proučavanju načina na koji se cisterna punila vodom. Prostor dvorišta, gdje je smještena, bio je dovoljno prostran za njeno ukopavanje i povoljno mjesto koje je omogućilo njezino punjenje. Prije nego što se nadovežemo na nalaze baza nosača galerije (kamenih stupaca), koji su vjerojatno izgrađeni nešto kasnije od cisterne u sklopu novoga preuređenja, ${ }^{27}$ važno je istaknuti da su na prostoru sektora I i VI-1 ustanovljene rupe
The cistern was possibly encircled with a stone wall, as was the case with the cistern at Medvedgrad. That assumption is supported by the fact that the end of the outer wall (SU 006) was indented. The cistern at Stari grad Novigrad na Dobri was probably built at the end of the $15^{\text {th }}$ century or the beginning of the $16^{\text {th }}$, during the first phase of the renovation of the medieval burg (Dobra) as an early Renaissance castle (when in the possession of Stjepan II (III) of Modruš or his son Bernardin Frankopan). This is indicated by the noticeable signs of constructional activities from that time, which is further supported by the historical fact that, in the period of Bernardin Frankopan, many of the Frankopan castles were renovated and upgraded.

\section{Organization of space around the cistern}

The cistern at Stari grad Novigrad na Dobri has all of the main characteristics of a filter-type cistern. It was dug into the bedrock and is located in the castle's yard in the place most suitable for water inflow from the castle's roofing. It can be assumed that the castle's roofing was made of clay tiles, and the main reason for that assumption is a fragment of a ceramic tile ( $F 765$, ochre colour, $2 \mathrm{~cm}$ thick) found in SU 167 (Sector VI-1). ${ }^{26}$ The found bases of stone pillars suggest the existence of the castle's roofing, as well. Their position proved to be quite important for the understanding of the principle by which the water was brought to the cistern. Stone pillars were probably set during the later renovation of the castle, after the cistern was already built. ${ }^{27}$ It is important to mention that holes of the former wooden pillars were found in sectors I and VI-1. These pillars may have supported some sort of a wooden construction (gallery). Right next 


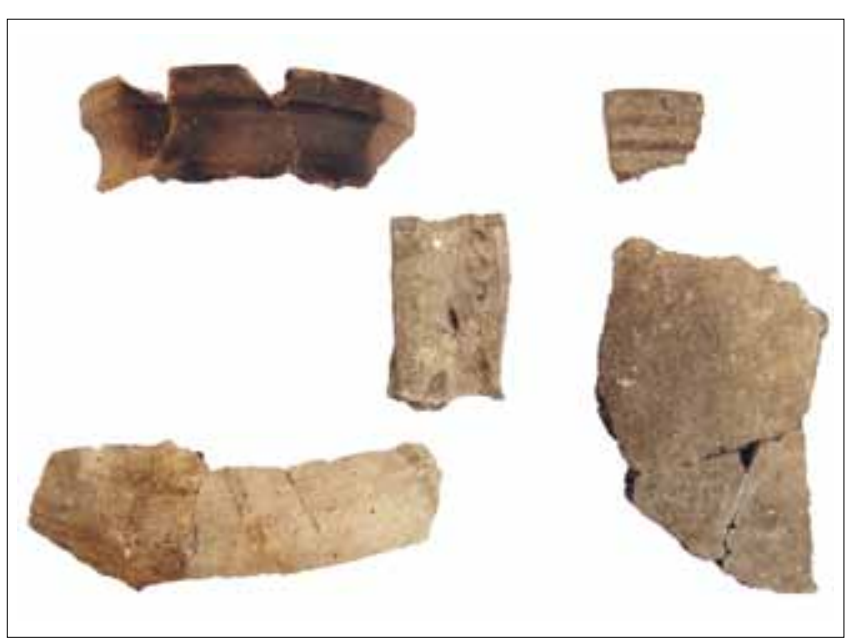

SLIKA 7. Keramika iz SJ 071 (Arhiv terenske dokumentacije Novigrad na Dobri) FIGURE 7. Ceramics from SU 071 (Excavation documentation archives, Novigrad na Dobri).

ranijih drvenih stupova koji su možda bili nosači neke ranije drvene konstrukcije (galerije) ili pak nadstrešnice koja se nalazila neposredno uz cisternu. Pokraj cisterne prilikom istraživanja na sjevernom dijelu dvorišta ustanovljeni su raniji slojevi koji su prethodili njezinoj izgradnji. Naime, radi se o zapunama ukopa SJ 055 (056), 052 (053), koje su možda bile dio neke ranije drvene konstrukcije, i slojevima SJ 065, 070 i 071 koji pokazuju ljudske aktivnosti na tom dijelu. $U$ tom pogledu posebno se izdvaja sloj SJ 071, koji karakterizira crna pougljenjena zemlja, a koji je lokaliziran samo na tom dijelu (na prostoru sektora I). Sloj SJ 071 prema cisterni je presječen, na što je ukazala pojava crvenkaste zemlje (SJ 061) bez nalaza kao i pojava kamena živca (SJ 153) u koji je cisterna ukopana. Ovakva situacija otprilike pojavljuje se i s ostalih strana cisterne. Primjerice, u zapadnom je dijelu zasip ukopa cisterne (SJ 008) bio načinjen od žutog pijeska, sitnog šljunka i sitnog kamenja.

Govoreći o ranijim slojevima, posebno valja izdvojiti SJ 071 u kojem se pojavila crna (pougljenjena) zemlja, što ukazuje na požar koji se dogodio unutar dvorca. Nije, međutim, poznato kada je nastao sloj gara. ${ }^{28}$ Možda je to bilo prilikom napada Osmanlija, o čemu piše i R. Lopašić, ali moguće je da se radilo o slučajnom požaru. U svakom slučaju, to će biti moguće utvrditi tek temeljitom i preciznom analizom te daljnjim istraživanjima ostalih dijelova kaštela. U izvješću istraživanja voditelj S. Mihelić, uz rezultate radiokarbonske analize zapuna SJ 055 i 056, navodi i rezultate analize sloja gara SJ 071 te pretpostavlja da bi se moglo raditi o vremenu ljudske aktivnosti koje je prethodilo izgradnji cisterne. Osim toga, sloj je gara SJ 071 u svome sastavu imao obilje nalaza od kojih se posebno izdvajaju ulomci grube (kuhinjske) keramike

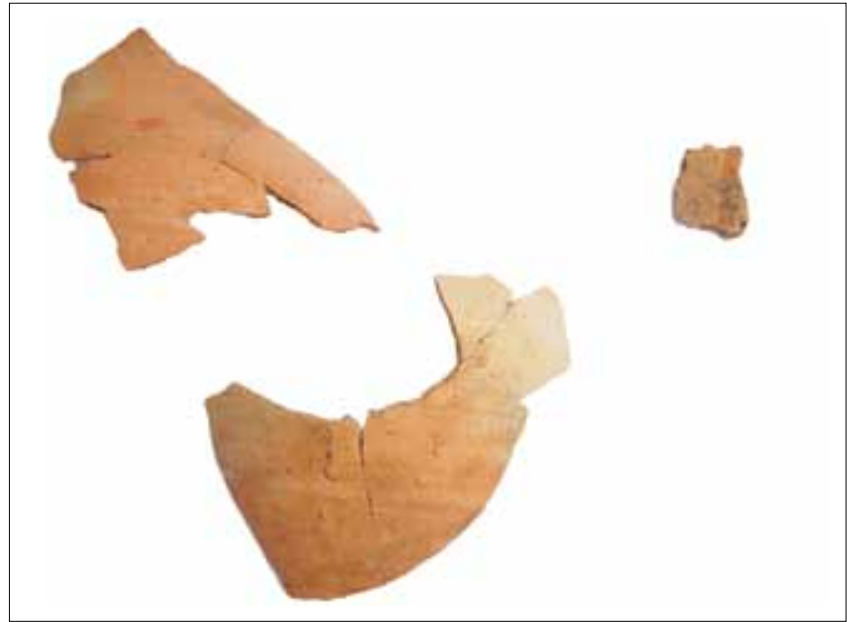

SLIKA 8. Ulomci posuda tankih stijenki (Arhiv terenske dokumentacije Novigrad na Dobri).

FIGURE 8. Fragments of thin-sided bowls (Excavation documentation archives, Novigrad na Dobri).

to the cistern, the layers which preceded its construction were found. They consist of the fillings of SU 055 (056) and SU 052 (053), which were perhaps part of some wooden construction earlier, and layers SU 065, 070 and 071, which show signs of human activity in that area. Among these layers, SU 071, which contains carbonized soil and is localized only in sector I, stands out. Towards the cistern this layer was cut off, which was indicated by the appearance of reddish soil (SU 061) without any findings, and also by the appearance of the bedrock (SU 153) into which the cistern was dug. For example, in the western part, a filling of the cistern $\operatorname{dig}(\mathrm{SU}$ 008) consisted of yellow sand, fine gravel and small rocks

Among the earlier layers, layer SU 071, which contains black (carbonized) soil, should be pointed out, because it indicates that there was a fire inside the castle, although it is not known when this burning occurred. ${ }^{28}$ It possibly happened during an Ottoman attack, which is mentioned by R. Lopašić, but it could have been an accidental fire, as well. In any case, the cause will remain unknown until further analysis and research of the other parts of the castle are conducted. In the report published in Hrvatski arheološki godišnjak, S. Mihelić brought forth not only the results of the radio-carbon analysis of fillings SU 055 and 056, but also the results of the analysis of layer SU 071 as well, with the assumption that this burned soil indicates human activity before the construction of the cistern. This layer also contained a lot of findings, among which there are significant fragments of brown, dark brown and black coarse (kitchen) ceramics, made by reduction and oxidation firing. These findings - fragments of pots made out of well-refined clay (Fig. 7), decorated below the rim - can be dated to the $14^{\text {th }}$ and $15^{\text {th }}$ centuries. 


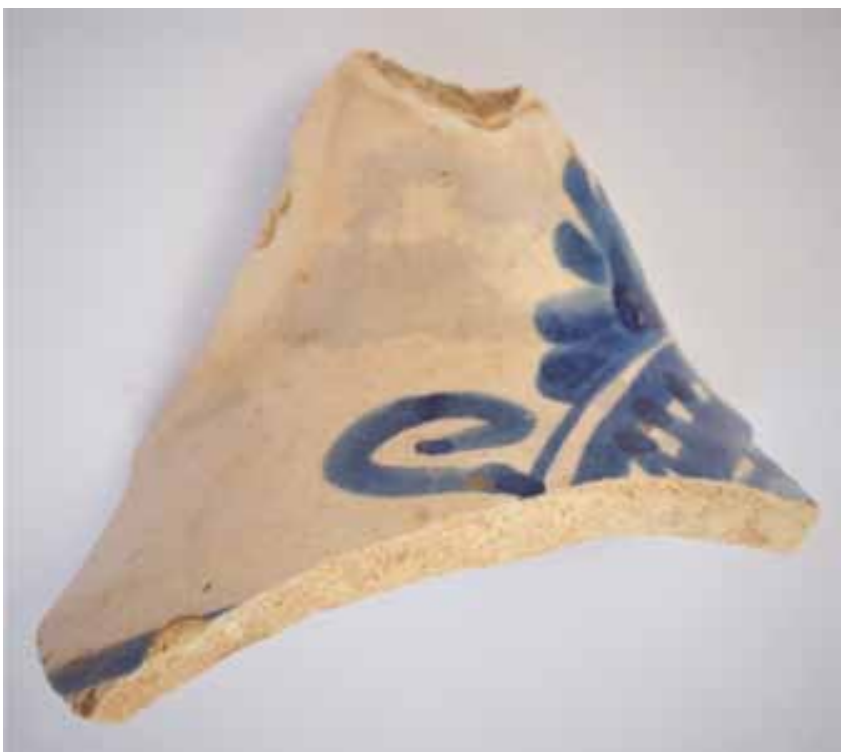

SLIKA 9. Nalaz trbušastog vrča majolike „Strogog stila” (Arhiv terenske dokumentacije Novigrad na Dobri).

FIGURE 9. Finding of a majolica jug, stile severo (Excavation documentation archives, Novigrad na Dobri).

smeđe, tamnosmeđe i crne boje, nastale redukcijskim i oksidacijskim pečenjem. Nalazi keramike mogu se datirati u 14. i 15. stoljeće. Radi se o ulomcima lonaca načinjenih od dobro pročišćene gline (sı. 7), koji su ukrašeni ispod oboda.

Od grube keramike zanimljiv je nalaz ulomka ručke lonca ukrašene žigosanim ukrasom koji se datira u 14. i 15. stoljeće. Šire analogije mogu se potražiti na prostoru Mađarske i Slovačke. Ovaj nalaz može se usporediti i s nalazom triju ručki iz sloja SJ 031, na kojima se nalazi ukras izveden dubokim urezima. Ručke su možda pripadale vrču za koji su nam analogni primjeri ručke na vrčevima pronađenim u Budimu, Csútu (Felcsútu), Ostrogonu i Višegradu, a koji se datiraju u 15. stoljeće. Na prostoru Hrvatske mogu se usporediti s nalazom ručke vrča ukrašene urezima s Burga Vrbovec u Klenovcu Humskom, koje su pronađene u SJ 018, 033 i 045, a datiraju se oko 15. stoljeća. ${ }^{29}$ Osim nalaza keramike iz sloja SJ 031, na Starom gradu Novigradu na Dobri pronađen je i novac Zweier, koji je kovan za vladavine slazburškog nadbiskupa i kardinala Matthäusa Langu von Wellenburga između 1519. i 1540. godine. Prema nalazu novca u SJ 031 nalazi keramike iz istog sloja mogli bi se datirati u razdoblje od 15. do prve polovine 16. stoljeća. ${ }^{30}$ Također, na dnu istoga sloja pronađeni su ulomci posuda tankih stijenki crvene do oker boje (sl. 8), na kojima se mogu vidjeti tragovi oblikovanja na lončarskom kolu.

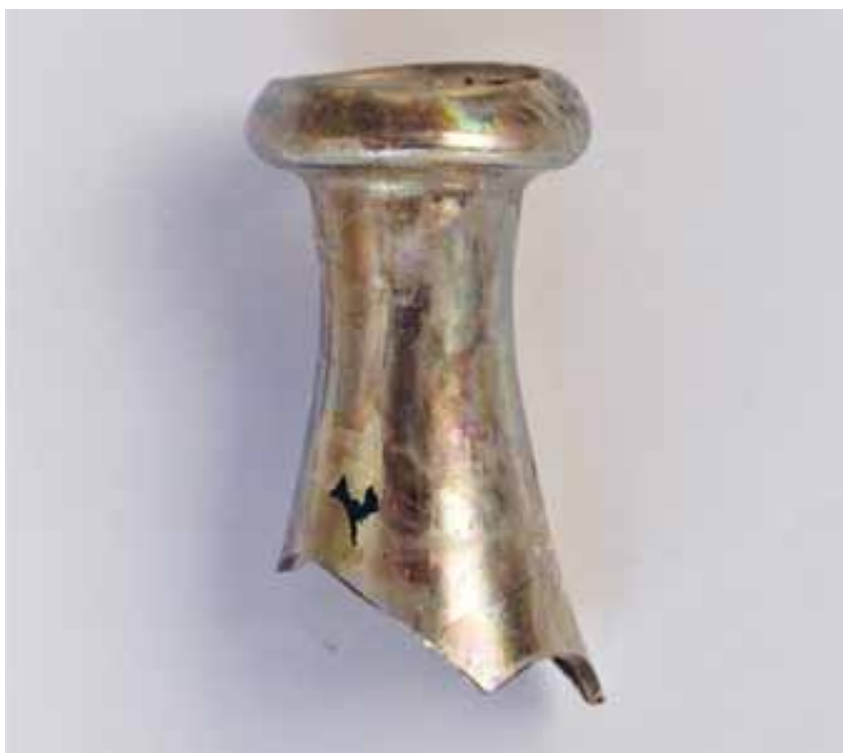

SLIKA 10. Staklena dvokonusna bočica PN 037 (Arhiv terenske dokumentacije Novigrad na Dobri).

FIGURE 10. Biconical flask SF 037 (Excavation documentation archives, Novigrad na Dobri)

Interesting example of coarse ceramics is a fragment of a jug handle, decorated with stamped ornaments. Wider analogies can be found in Hungary and Slovakia. This finding can be compared to the three handles, decorated with deep incisions, found in layer SU 031. The handles perhaps belonged to a jug similar to those found in Buda, Csút (Felcsút), Esztergom and Visegrád, all dated to the $15^{\text {th }}$ century. In Croatia, one analogous finding is that from Burg Vrbovec, in Klenovac Humski, where a carved jug handle was found in layers SU 018, 033 and 045, which can be dated to the $14^{\text {th }}$ and $15^{\text {th }}$ centuries. ${ }^{29}$ Except for the findings of ceramics in layer SU 031 at Stari grad Novigrad na Dobri, a Zweier coin was found, which belongs to the tenure period of Matthäus Lang von Wellenburg, Cardinal and Prince-Archbishop of Salzburg, and was minted between 1519 and 1540 . On the basis of this coin, the ceramics found in layer SU 031 can be dated to the $15^{\text {th }}$ century and into the first half of the $16^{\text {th }} . .^{30}$
29 Holl 1955, 171, kép. 46; Tkalčec 2010b, 466. Vrčevi sive boje, nastali redukcijskim pečenjem, pripadaju bečkim radionicama. Ulomak ručke vrča ukrašene urezima iz SJ 033 S Burga Vrbovec pripada tipu kljunastih vrčeva, koji predstavljaju čest nalaz na prostoru Mađarske i Slovačke, gdje su datirani u široki vremenski okvir od 13. do 16. stoljeća. Primjerak iz SJ 033 mogao bi pripadati 14. ili 15. stoljeću (Tkalčec 2010b, 466). Vrčevi s Burga Vrbovec, koji na sebi imaju urezane ukrase, prikazani su na tabli 5 (Tkalčec 2010b, 476, sl. 111, 118, 122).

30 Mihelić 2010, 312.
29 Holl 1955, 171, kép. 46; Tkalčec 2010b, 466. Grey jugs, made by reduction firing, belong to Viennese manufactures. A fragment of a carved jug handle found in SU 033 belongs among beak-like jugs, which is a very common finding in Hungary and Slovakia, where these jugs are dated to the period from the $13^{\text {th }}$ century to the $16^{\text {th }}$. The fragment from SU 033 could be dated to the $14^{\text {th }}$ or $15^{\text {th }}$ century (Tkalčec 2010b, 466). Examples of jugs with decorative carvings from Burg Vrbovec are shown in Table 5 (Tkalčec 2010b, 476, sl. 111, 118, 122).

30 Mihelić 2010, 312 


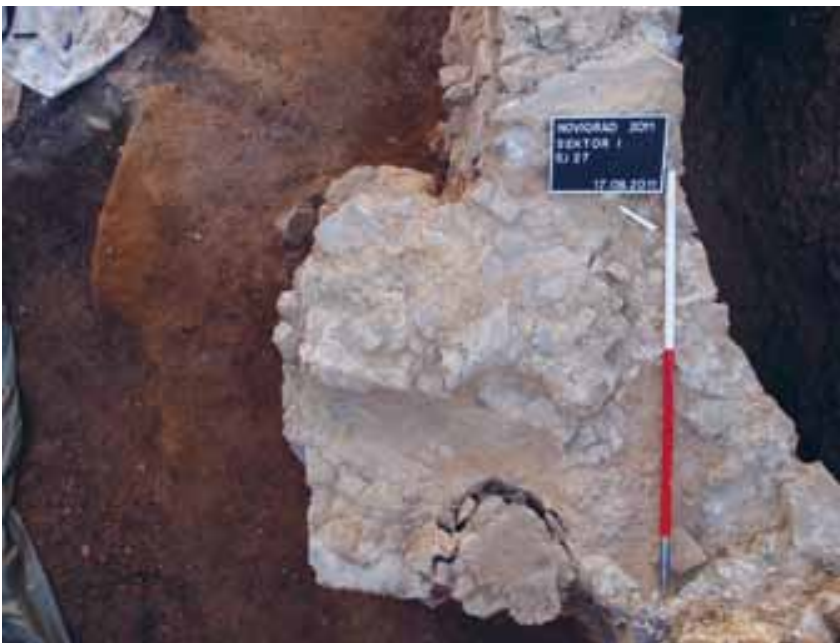

SLIKA 11. Kameni stupac SJ 027 (Arhiv terenske dokumentacije Novigrad na Dobri)

FIGURE 11. Stone pillar SU 027 (Excavation documentation archives, Novigrad na Dobri).

SLIKA 11. A. Kameni stupac SJ 012 (Arhiv terenske dokumentacije Novigrad na Dobri).

FIGURE 11A. Stone pillar SU 012 (Excavation documentation archives Novigrad na Dobri)

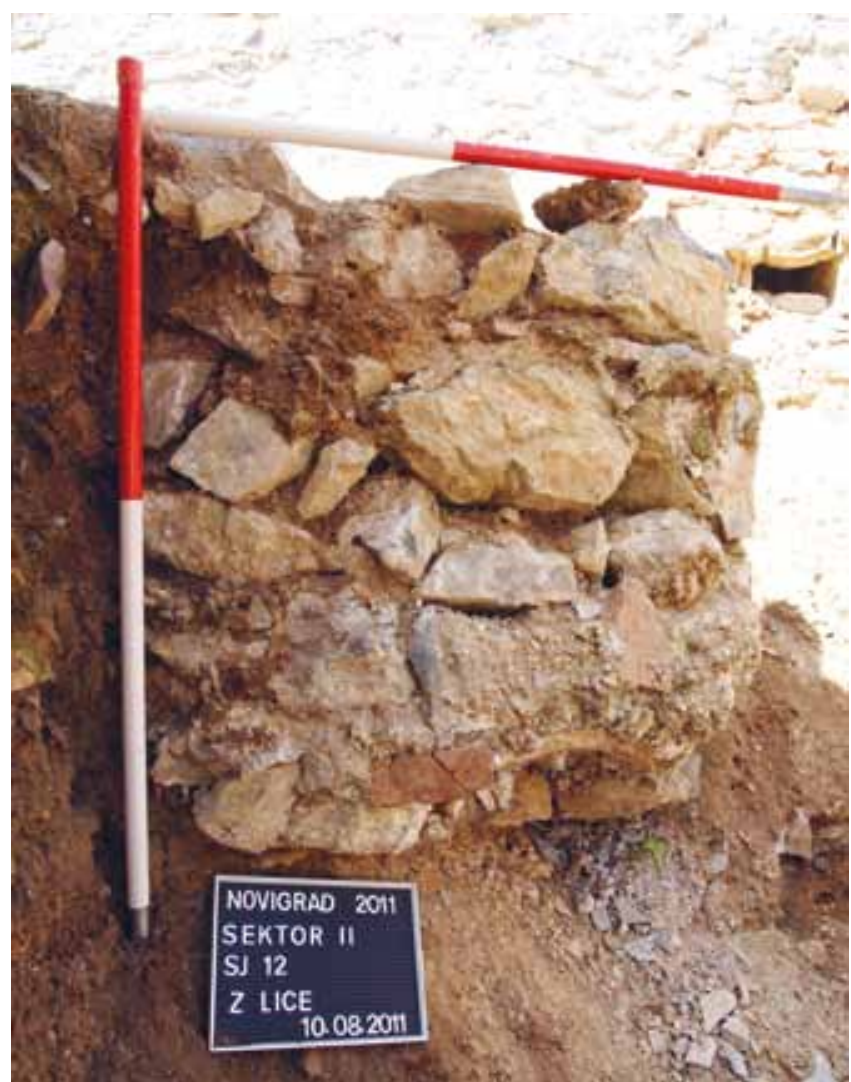

At the bottom of the same layer were found fragments of a bowl that had thin sides, red and ochre in colour (Fig. 8), with visible traces that indicated usage of a pottery wheel.

Among other findings of ceramics, a special group of fine imported majolica should be pointed out, an interesting example of which is a fragment of a jug (Fig. 9) found in SU 189, type majolica ware (stile severo), decorated with blue vegetal ornaments on a white opaque base, dated to the $15-16^{\text {th }}$ century. ${ }^{31}$ Other findings found around the cistern, which are connected with housing activities, include glass: for example, a biconical flask (Fig. 10; SF 034 from SU 191) dated to the $15-16^{\text {th }}$ century. ${ }^{32}$

\section{Gallery girders and the situation in sectors I and VI-1}

Stone pillars (gallery girders; SU 012 (sector II), 029 (155) (sector $\mathrm{VI}-1$ ) and 027 (sector I)) were made of irregular stone blocks and connected with a thick layer of lime. The appearance and condition of the gallery and pillars are visible in photographs kept in the State Archives in Karlovac. ${ }^{33}$ The pillars supported the gallery by the western castle wall, one of them (Fig. 11; SU 027) leaning uza zapadni zid, dok je kameni stupac SJ 027 (sl. 11) bio naslonjen

31 Gusar 2010, 119; Vitalievna-Ginkut 2019, 192, Fig. 5.

32 Höll-Gyürky 1986, 70-72; Delonga 1987, 93, 103; Šimek 2010, 308-309.

33 Fotografija iz 40-ih godina 20. stoljeća, koja prikazuje unutarnje dvorište dvorca u kojem se nalazila i kruna cisterne (HR-DAKA-0147).
31 Gusar 2010, 119; Vitalievna-Ginkut 2019, 192, Fig. 5

32 Holl-Gyürky 1986, 70-72; Delonga 1987, 93, 103; Šimek 2010, 308-309.

33 Photograph of the cistern's crown from the 1940S (HR-DAKA-0147) 


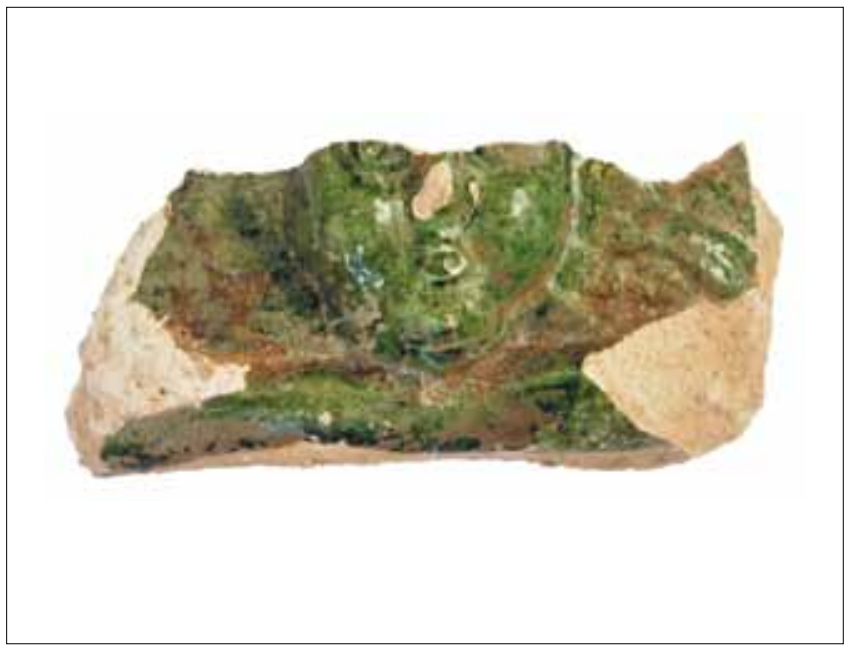

SLIKA 12. Zelenoglazirani pećnjak s prikazom ljudskog lika - anđela (Arhiv terenske dokumentacije Novigrad na Dobri).

FIGURE 12. Green-glazed tile showing a human face with wings in the background (Excavation documentation archives, Novigrad na Dobri).

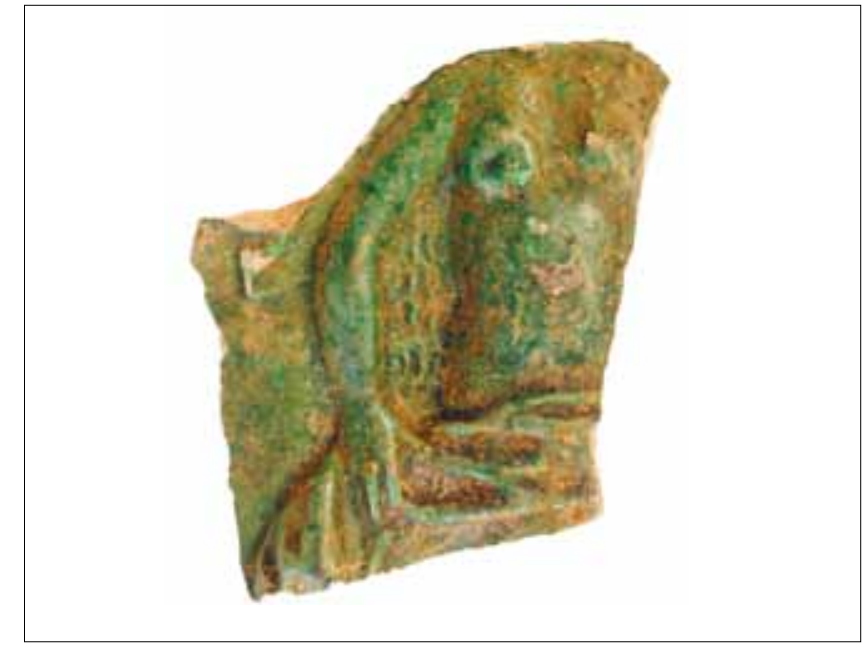

SLIKA 13. Zelenoglazirani pećnjak s prikazom nagog ženskoga lika (Arhiv terenske dokumentacije Novigrad na Dobri).

FIGURE 13. Green-glazed tile showing a naked female figure (Excavation documentation archives, Novigrad na Dobri).
SLIKA 14. Pećnjak s prikazom lava u heraldičkom položaju (Arhiv terenske dokumentacije Novigrad na Dobri).

FIGURE 14. Tile showing a lion in heraldic position (Excavation documentation archives, Novigrad na Dobri).

na cisternu (SJ 006) te je bio nosač iste galerije koja se protezala prema istočnom dijelu kaštela. Teško je govoriti o točnom vremenu ovoga preuređenja, ali ono se moglo dogoditi u vrijeme Patačića. Sigurno je da je izgradnja pojedinih stupaca, a posebno temelja baze stupca S) 029 (155; sl. 11a; dimenzija duljine $100 \mathrm{~cm}$, širine $65 \mathrm{~cm}$ i visine $130 \mathrm{~cm}$, izrađenog od neobrađenoga kamenja koje je složeno i povezano debelim slojem žbuke) oštetila strukturu SJ 196 (zapuna SJ 199; dimenzija duljine $70 \mathrm{~cm}$ širine $50 \mathrm{~cm} \mathrm{i}$ visine $40 \mathrm{~cm}$ )

Struktura SJ 196 je bila načinjena od poluobrađenih kamenih blokova i manjega neobrađenog kamenja, vezanog razmrvljenom žbukom koja je miješana sa sivim šljunkom s primjesom od oblutaka veličine $1 \mathrm{~cm}$. Prilikom preuređenja, kao građevni materijal, sekundarno su primijenjeni odbačeni pećnjaci. Među pećnjacima posebno se ističe ulomak zeleno glaziranog pećnjaka s prikazom ljudskog lica s krilima u pozadini (anđela; PN 041) iz SJ 196 (sl. 12), on the cistern (SU 006). It is not known when the gallery was built: possibly in the Patačić period. The construction of some of the pillars (particularly pillar SU 029 (155), length $100 \mathrm{~cm}$, width $65 \mathrm{~cm}$ and height $130 \mathrm{~cm}$, made of rough stone material connected with a thick layer of mortar; Fig. 11a) caused damage to structure SU 196 (filling SU 199, length $70 \mathrm{~cm}$, width $50 \mathrm{~cm}$ and height $40 \mathrm{~cm}$ ).

Structure SU 196 was made of semi-processed stones of different sizes, lined and filled with mortar mixed with grey gravel and pebble admixture. Secondarily used fragments of stove tiles were used as building material, as well. Standing out among them is a piece of green glazed tile depicting a human face with wings in the background (an angel; special finding - SF 041; Fig. 12), which can be dated to the first half of the $16^{\text {th }}$ century. Another interesting fragment of stove tile is a green-glazed one (SF 043) from the mid-16 $6^{\text {th }}$ century depicting a naked woman (Fig. 13), her right hand holding a cloth. In addition, several fragments 
koji se može datirati u prvu polovinu 16. stoljeća, i ulomak zeleno glaziranog pećnjaka (PN 043) iz SJ 207, koji prikazuje nagu ženu koja desnom rukom drži tkaninu (sl. 13), iz sredine 16. stoljeća.

Posebno je zanimljiv i nalaz pećnjaka iz SJ 190 i 191 s prikazom stiliziranog lava u heraldičkom položaju (PN 023, 025, 035 i N 864 i 904; sl. 14), a datira se u sredinu i drugu polovinu 15. i početak 16. stoljeća. ${ }^{34}$

Strukturi SJ 196 slična je struktura SJ 204 (sektor VI-1, duljine 100 $\mathrm{cm}$, širine $100 \mathrm{~cm}$ i visine $25 \mathrm{~cm}$ ), načinjena od neobrađenoga pločastog kamenja raznih veličina od 5 do $20 \mathrm{~cm}$ i nepravilnih kamenih grumena i pećnjaka. Struktura je bila vezana finom žbukom (bijele do svijetlonarančaste boje).

S druge strane, strukture SJ 196 i 204 ne mogu se usporediti s bazama stupova SJ 012, 027 i 029 (155) jer nisu povezive s njihovim dimenzijama i načinom gradnje. Navedene su strukture možda dio nekoga urušenja ili pak starijeg zida koji je srušen prilikom izgradnje galerije. Razne intervencije na dijelu sektora I i VI-1 vezane uz rušenje, ukopavanje i poravnavanje vidljive su i u slojevima SJ 160, 161, 162, 177, a odnose se na aktivnosti vezane uz izgradnju baze stupa galerije SJ 029 (155). Građevinske su intervencije poduzete i prilikom izgradnje baza stupa SJ 027, a vidljive su u slojevima SJ 042, 058 i 061.35

\section{Dva kanala i tunel}

Kameni kanal (SJ 015, zapunjava SJ 014) proteže se u smjeru zapad - istok (između sektora I i II), počevši od kamenog stupca (S) 029; na zapadu) prolazeći kroz vanjski zid cisterne (SJ 006) i kroz filter (SJ 060) prema središnjem spremniku za vodu (SJ 004, istok). Kanal je ukopan plitko u zasip ukopa oko cisterne (SJ 008), a ispod njega su se nalazili slojevi zasipa oko ukopa cisterne SJ 058, 064, 042 i 061. Bio je načinjen od većega pločastog kamenja, dok je na krajnjem dijelu na istočnoj strani bio omeđen većim komadima kamena položenim na kameno popločanje. Tok je kanala na ulazu u cisternu (vanjski zid, SJ 006) blago natkriven te je na tome mjestu pokriven gornjom kamenom pločom. Prema tome, može se zaključiti kako je kanal bio odmah ispod popločanja dvorišta, položen prilično plitko u odnosu na „kanal-tunel“.

Posebna, moguće naknadno izgrađena građevina, prislonjena je na vanjski zid cisterne i ulazi u središnji spremnik za vodu. Prilikom pisanja rada nazvana je „kanal-tunel“. Riječ je o podzemnoj građevini nepoznate namjene koja se od vanjskog zida cisterne nastavlja južno u nepoznatom smjeru. Sastoji se od paralelnih zidova tunela (SJ 100, 102, 110, 111, 112, 114, 115 i 120) i kanala (S) 123, 122). S obzirom na to da voditelj istraživanja koristi termin have been found (from SU 190 and SU 191) of a tile depicting a stylized lion set in heraldic position (Fig. 14; SF 023, 025, 035, and $\mathrm{F} 864,904)$. This tile is dated to the middle/second half of the $15^{\text {th }}$ century and the beginning of the $16^{\text {th }} .{ }^{34}$

Structure SU 204 (sector VI-1, length $100 \mathrm{~cm}$, width $100 \mathrm{~cm}$ and height $25 \mathrm{~cm}$ ) is similar to SU 196. It is made of irregular unprocessed stones varying in size (from 5 to $20 \mathrm{~cm}$ ), stone lumps and stove tiles, all bound with fine lime (white and light orange in colour).

On the other hand, structures SU 196 and 204 cannot be connected with the bases of pillars SU 012, 027, and 029 (155) because they are different in dimensions and type of masonry. Those structures (SU 196, 204) possibly result from some collapse, or part of a former wall that had been torn down just before the gallery was built. Various interventions in sectors I and VI-1 made in earlier periods of renovation are presented to us in layers SU 160, 161,162 and 177, and they relate to the activities when SU 029 (155) was built. Other interventions were also made during the building of SU 027, and the results of those activities are visible in SU 042, 058 and 061. ${ }^{35}$

\section{Two channels and a tunnel}

Stone tunnel SU 015, which fills SU 014, lies east-west between sectors I and II. It starts from the stone pillar (SU 029) and goes through the outer cistern wall (SU 006) and filter (SU 060) into the central water tank (SU 004). The channel was shallowly dug into SU 008, and beneath it was a layer of the cistern's dug filling SU 058, 064, 042 and 061. This channel was made of larger stone slabs and was bounded by irregular larger stone pieces at its eastern end. More regular stone blocks are set on the eastern side and laid on the stone paving. The part of the channel entering the cistern through the outer cistern wall (SU 006) was covered with an upper stone slab. On this basis we can assume that this channel was set just under the surface of the castle yard, laid at a significantly shallower depth than the 'tunnel/channel'.

A special construction, possibly subsequently built, that leaned on the outer wall of the cistern and entered the water tank is here called a 'tunnel/channel'. It is an underground structure of unknown purpose which, after leaving the outer cistern wall, continues to the south in an unknown direction. It consists of parallel tunnel walls (SU 100, 102, 110, 111, 112, 114, 115 and 120) and a channel (SU 122, 123). The term 'tunnel', used in the text
34 Škiljan 2015. Pećnjak pronađen na Starom gradu Novigradu na Dobri u sloju SJ 196 (PN 041) usporediv je s nalazom pećnjaka s Nove Vesi (Zagreb), datiranog u prvu polovinu 16. stoljeća (Škiljan 2015, T. 98, sl. 369) i Staroga grada Samobora, odakle je pećnjak datiran oko 1500. godine (Škiljan 2015, T. 57, sl. 258). Nadalje, primjerak pećnjaka (PN 043) iz SJ 207, premda sačuvan fragmentarno, usporediv je s nalazom pećnjaka iz dvorca Velikog Tabora, koji je datiran u sredinu 16. stoljeća (Škiljan 2015, T. 53, sl. 249). Pećnjak, čiji su ulomci pronađeni u SJ 190 i 191 (PN 023, 025, 035 i N 864 i 904), usporediv je s nalazom pećnjaka s lokaliteta Gudovac, koji cjelovito prikazuje lava, a datira se oko 1500. godine (Škiljan 2015, T. 58, sl. 260).

35 Mihelić 2012, 335
34 Škiljan 2015. A fragment of a stove tile found at Novigrad na Dobri in SU 196 (SF 041) can be compared with a fragment of a stove tile from Nova Ves (Zagreb), dated to the first half of the $16^{\text {th }}$ century (Škiljan 2015, T. 98, sl. 369), and one from Stari grad Samobor, dated to around 1500 (Škiljan 2015, T. 57, sl. 258). An example of a stove tile (SF 043) from SU 207, though only partially preserved, can be compared with a finding of a stove tile from the castle of Veliki Tabor, dated to around the middle of the $16^{\text {th }}$ century (Škiljan 2015, T. 53, sl. 249). A stove tile, fragments of which were found in SU 190 and 191 (SF 023, 025, 035 and F 864 and 904) can be compared with one showing a lion from the site of Gudovac, dated to around 1500 (Škiljan 2015, T. 58, sl. 260). 
SLIKA 15. Pogled na istraženi kanal-tunel (Arhiv terenske dokumentacije Novigrad na Dobri). FIGURE 15. View of the excavated tunnel/channel (Excavation documentation archives, Novigrad na Dobri).

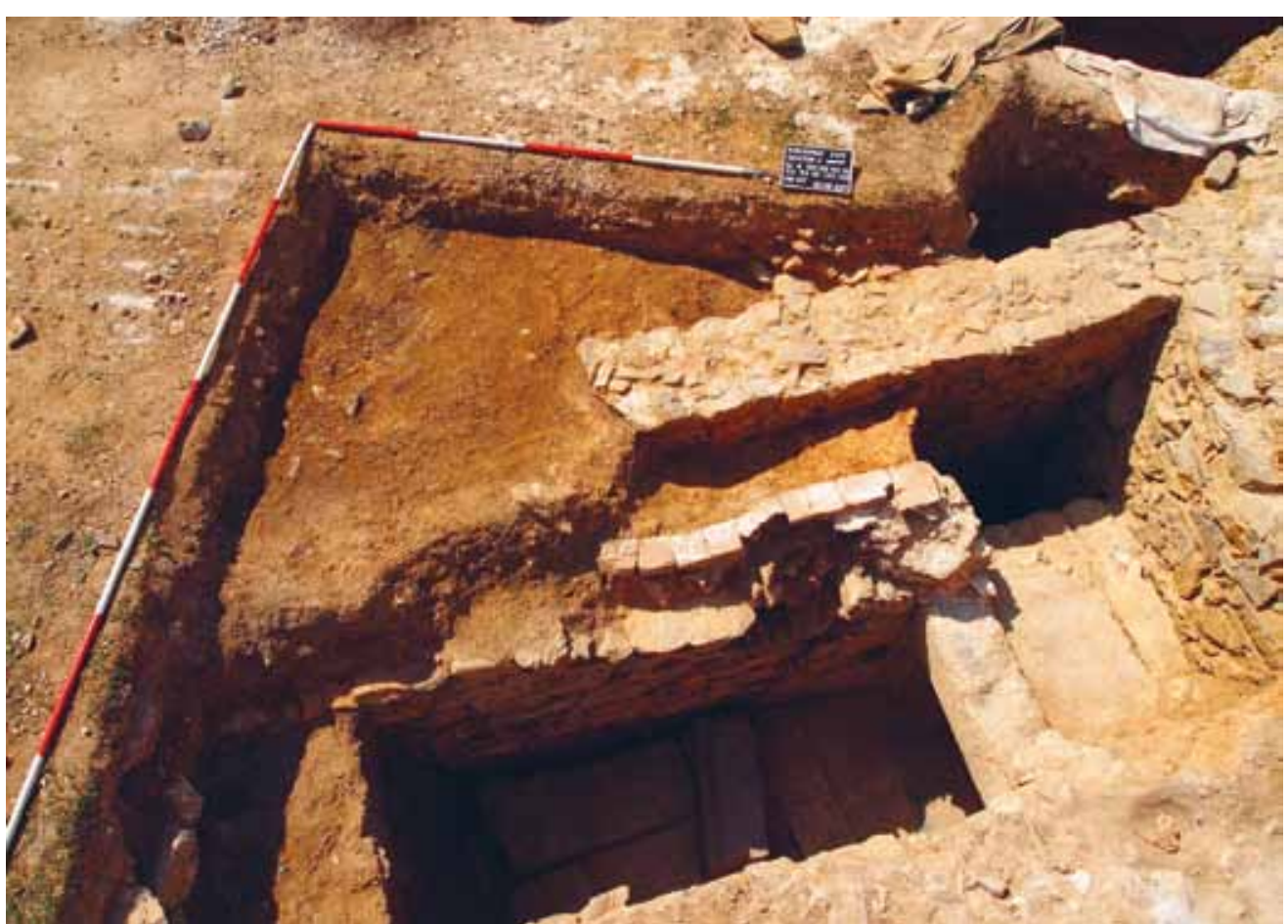

„tunel“, odlučili smo ga zadržati i nadopuniti riječju „kanal“. Kanal-tunelu se s jugoistočne strane paralelno nalazio zid (SJ 100), načinjen od kamenih blokova povezanih žbukom (sl. 15). Između tog zida (SJ 100) i zida kanal-tunela, načinjena od kamena povezanog žbukom i malog zidića od opeke (SJ 102, ${ }^{36} 110,111,113$ ), nalazila se zapuna od crvenkaste pjeskovite zemlje slična SJ 060, $061 \mathrm{i}$ 135 (sektor V). Nasuprot SJ 100, sjeveroistočno od tunela, nalazila se struktura od kamena i cigle, SJ 099, a činilo ju je veće pločasto kamenje i komadi opeke koji su tvorili dio popločanja. ${ }^{37}$

$\mathrm{Na}$ zidu od kanala-tunela bile su naslagane opeke, koje su bile obilato povezane žbukom (SJ 102), a možda su nastale kasnijim intervencijama na kanal-tunelu. Na mjestu kontakta između kanala i tunela sačuvan je dovratnik i nadvratnik (SJ 110), a taj je dio tunela natkriven kamenom pločom pravokutnog oblika (S) 112). Na tome mjestu izmjenjuju se nadvratnik (SJ 110), pravokutna ploča (SJ 112) i nadvratnik (SJ 115) koji je prislonjen uz vanjski zid cisterne (sl. 16). Podno nadvratnika pronađen je prag s utorima namijenjenim za držanje željezne rešetke (SJ 110). Prostor kanala-tunela prema jugoistoku bio je popločan pravokutnim kamenim pločama (SJ 120) koje su bile položene okomito i vodoravno u smjeru kanala-tunela. Na dnu je pronađen dio dovratnika (kamena profilirana greda duljine oko $80 \mathrm{~cm}$, a širine oko $25 \mathrm{~cm}$; SJ 137) koji je vjerojatno nosio dio pokrova tunela. Prema tome, možemo pretpostaviti da je kanal-tunel bio građen tako da su se izmjenjivali podupirači i ploča koja se nalazila između njih (greda - ploča - greda) published in Hrvatski arheološki godišnjak, is here expanded with the word 'channel'.

On the southeast side, parallel to the 'tunnel/channel', stood a stone block wall (SU 100). The space between this wall (SU 100) and the tunnel wall (Fig. 15; SU 102, ${ }^{36} 110,111,113$ ), made of stone bound with mortar, was filled with reddish sandy soil, as in SU 060,061 and 135 (sector V). Across SU 100, in a northeast direction from the tunnel, there was structure SU 099 (made from bigger stone slabs and brick fragments), which formed a pavement. ${ }^{37}$

The top of the tunnel wall was lined with bricks pointed with lime (SU 102), perhaps as a result of the later interventions on the tunnel. On the 'tunnel/channel' junction, a jamb and lintel were preserved (SU 110), and this part of the tunnel was covered with a rectangular stone slab (SU 112). At this spot were set a lintel (SU 110), a rectangular stone slab (SU 112), and another lintel (SU 115), which leaned on the outer cistern wall (Fig. 16). A sill with grooves for an iron grid (SU 110) was found under the lintel. The tunnel space was paved in the southeast direction with stone slabs (SU 120) which were set vertically and horizontally along the tunnel. At the bottom of the tunnel was found a fragment of the jamb (profiled stone beam, length approximately 80 $\mathrm{cm}$ and width $25 \mathrm{~cm}$; SU 137) that probably supported part of the tunnel covering. It can be assumed that the 'tunnel/channel' was covered with stone slabs laid upon the supporting lintel-jamb constructions set along the 'tunnel/channel' (beam-slab-beam).
36 Radi se o naslagi opeke povezane žbukom koja je bila presječena sondom iz 2003. godine.

37 Mihelić 2011, 336. Ispod SJ 099 (niveliranog urušenja) tijekom istraživanja 2012. naziralo se postojanje nekih novih struktura koje su se očitovale u postojanju kompaktnije zemlje ispod.
36 This is a sediment of brick bound with mortar, which was intersected by the trench in 2003

37 Mihelić 2012, 336. During the excavations in 2012 under SU 099 (layer of collapse) there appeared signs of the existence of new structures. 


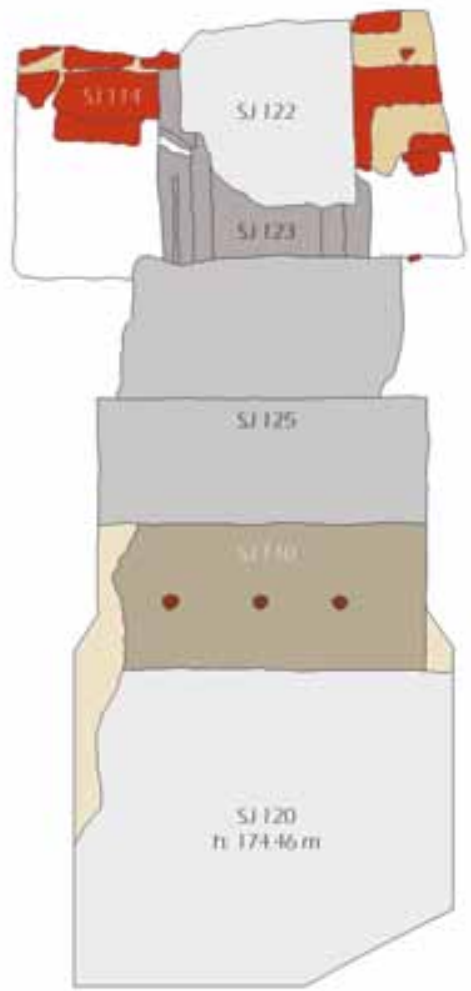

SLIKA 16. Tlocrt tunela (sektor III; izradile I. Kostešić, A. Franjić). FIGURE 16. The layout of the tunnel (sector III; made by I. Kostešić, A. Franjić).

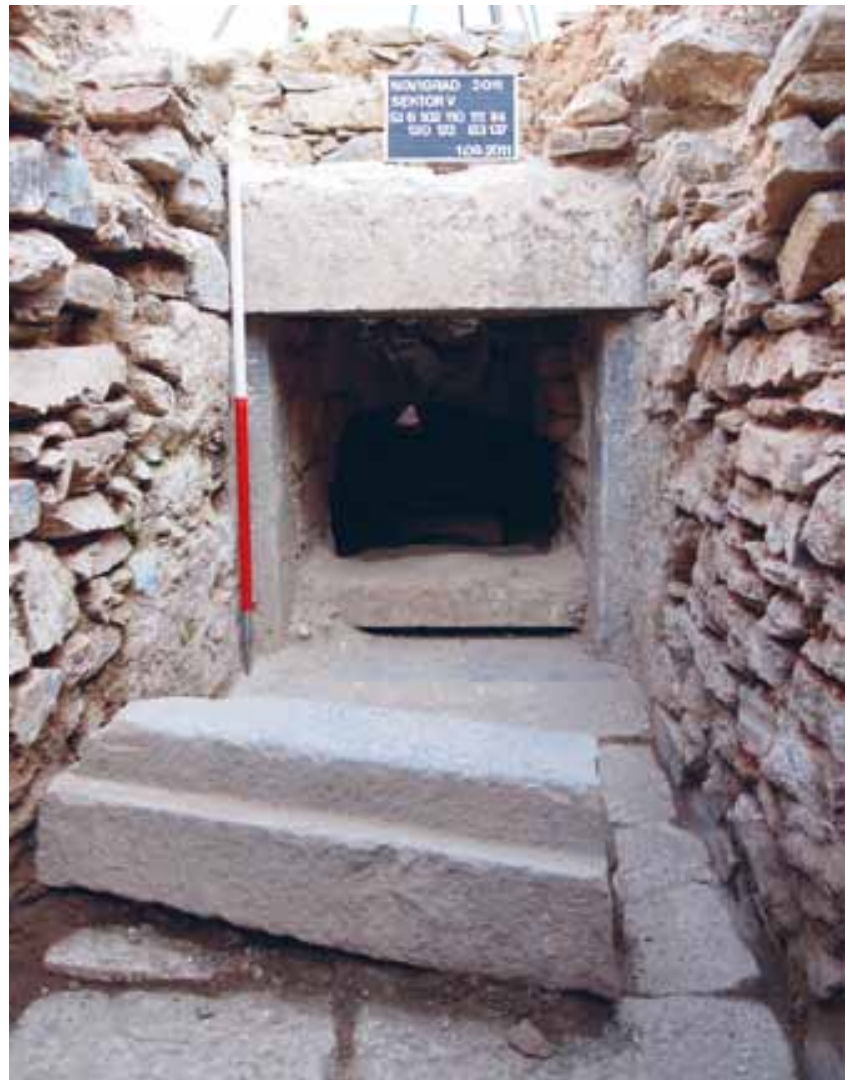

SLIKA 17. Ulaz u tunel (Arhiv terenske dokumentacije Novigrad na Dobri). FIGURE 17. Draft of the tunnel entrance (Excavation documentation archives, Novigrad na Dobri).
Dio kanala-tunela bio je pregrađen opekom vezanom žbukom (možda se radilo o popravku). Na mjestu kontakta između kanala-tunela i vanjskog zida cisterne tunel prestaje, a kanal (SJ 123) prolazi kroz zid i ulazi u središnji spremnik za vodu (SJ 004; sl. 17). Iznad njega se nalaze dvije kamene klesane ploče (SJ 122). Na dnu tunela pronađeni su ostaci drvenih greda (dasaka) za koje je ustanovljeno da su nastale recentnom građevinskom intervencijom na tunelu. ${ }^{38}$ Vrijeme nastanka kanala-tunela nije moguće ustanoviti. Usmjerenje ostatka kanala-tunela na prostoru dvorišta također je nepoznato. ${ }^{39}$ Glede same namjene, postoji mogućnost da je dovodio vodu u cisternu, ako se uzme u obzir navod iz Izvješća objavljenog u Hrvatskome arheološkom godišnjaku. Naime, u izvješću stoji kako je razlika između visine kanalice u cisterni (iznosi 174,386 m) i unutar tunela (iznosi 174,438 m) iznosi $0,052 \mathrm{~m}$, a to sugerira nagib prema unutrašnjosti spremnika. Ovakva situacija nije uobičajena za filter-cisterne jer se pristigla voda uglavnom prikupljala u prostor filtera, odakle bi ulazila u središnji spremnik. Kako bi se bolje razumjela namjena i vrijeme izgradnje kanala-tunela, potrebno je provesti nastavak arheoloških istraživanja.
Part of the 'tunnel/channel' was partitioned with mortar-bound bricks (perhaps due to later repairs). At the point where it reaches the cistern's outer wall, the tunnel ends, and the channel (SU 123) goes through the wall and into the central water tank (SU 004; Fig. 17). Above the channel two carved stone slabs (SU 122) are set. At the bottom of the channel, remains were found of wooden beams installed during more recent interventions in the cistern construction. ${ }^{38}$ The exact time of the construction of the 'tunnel/channel' cannot be determined, nor its orientation in the yard. ${ }^{39}$ As for its purpose, according to the report published in Hrvatski arheološki godišnjak, it was possibly made for bring ing water to the cistern. The difference in height between the channel in the cistern $(174.386 \mathrm{~m})$ and the channel in the tunnel ( $174.438 \mathrm{~m})$, a total of $0.052 \mathrm{~m}$, shows that this construction was inclined towards the inside of the tank. A situation like this is not common among well-filtered cisterns, because the water would usually be brought into the filter first, from which it would enter the central tank.

\section{Mihelić 2012, 335-336; 2013, 409-413}

39 Mihelić 2011, 335-336. Mihelić pretpostavlja da je tunel mogao imati funkciju tajnog prolaza. S druge strane, Bänteli, koji je pokušao objasniti funkciju sličnog tunela, koji je istraživao u gradu Schaffhausenu, smatra da se takvi tuneli često pogrešno interpretiraju kao tajni prolazi, dok se, po njegovu mišljenju, u stvari radi o podzemnim kanalima za vodu (Bänteli 2009, 171).

\section{Mihelić 2012, 335-336; 2013, 409-413.}

39 Mihelić 2011, 335-336. Mihelić assumes that the tunnel could have been used as a secret passage in case of siege. On the other hand, Bänteli, who tried to explain the function of a similar tunnel in the town of Schaffhausen, be lieves that these tunnels are often misinterpreted as secret passages of some sort and assumes that they were constructed as underground water channels (Bänteli 2009, 171) 


\section{Zaključak}

Filter cisterna na Starom gradu Novigradu na Dobri sagrađena je tijekom preuređenja srednjovjekovnog burga (Dobre) u kaštel u vrijeme Bernardina Frankopana na prijelazu iz 15. u 16. stoljeće, a u obzir treba uzeti da je taj proces započet u vrijeme Bernardinova oca, Stjepana II. (III.) Modruškog. Cisterna je smještena ciljano u dio kaštela koji je bio najizloženiji slijevanju oborinskih voda s obližnjih krovova. Prema svome obliku, cisterna je slična ranijim srednjovjekovnim primjerima, a novovjekovnom građevinom je čine jedino vrijeme nastanka i tipološko-vremenska pripadnost građevine u kojoj je izgrađena (kaštel). Ostale komponente, kao što su kanali, razina obrađenosti kamena, vezivni materijal, položaj i izgled vijenca možemo u boljoj ili lošijoj varijanti potražiti i u razdoblju razvijenog te kasnoga srednjeg vijeka na prostoru središnje Europe. Istražena novigradska cisterna pokazuje kako je prilikom preuređenja u kaštel korišteno poznato i provjereno znanje sustava te načina vodoopskrbe iz vremena razvijenog $i$ kasnog srednjega vijeka dorađeno iskustvom i spretnošću graditelja.

\section{Zahvale}

Zahvaljujem se voditelju istraživanja na Starom gradu Novigradu na Dobri i ravnatelju Arheološkog muzeja u Zagrebu Sanjinu Miheliću na ustupljenoj dokumentaciji i pomoći, kao i Ivi Kostešić na informacijama vezanima uz terenska istraživanja cisterne. Zahvaljujem se i ostalim sudionicima u istraživanju na Starom gradu Novigradu na Dobri (2009. - 2012.) na doprinosu prilikom izrade dokumentacije pomoću koje je načinjen ovaj članak. Posebnu zahvalu dugujem dr. sc. Tatjani Tkalčec (Institut za arheologiju) na podršci pri pisanju teme vodoopskrbe, kao i na smjernicama i vrijednim savjetima u vezi pisanja ovog rada. Također, zahvaljujem se djelatnicima Državnog Arhiva u Karlovcu na susretljivosti i ustupljenim fotografijama Staroga grada Novigrada na Dobri.

\section{Conclusion}

The well-filtered cistern (filter-type) at Stari grad Novigrad na Dobri was built in the period of rearrangement of the medieval burg (Dobra) as an early modern castle, in the period of Bernardin Frankopan at the turn of the $16^{\text {th }}$ century. This process started in the time of Bernardin's father, Stjepan II (III) of Modruš. The cistern is set in the castle's inner yard, in the place most suitable for bringing water from the castle's yard and roofing. This cistern is a typical example of the medieval construction style, and the main elements connecting it to the early modern period are the time of its construction and the fact that it was built within an early modern castle. Others of its components, such as channels, level of stone shaping, binding materials, position and appearance of the cistern wreath, can be found in the high and late medieval periods in Central Europe. The researched cistern at Novigrad na Dobri, therefore, shows us the main principles and understanding of water management applied during its construction, many of which had been known and applied since the high medieval period.

\section{Acknowledgments}

I would like to thank the head of the Stari grad Novigrad na Dobri excavation and the director of the Archaeological Museum in Zagreb, Sanjin Mihelić, for allowing me to use the field research documentation, as well as for his overall help, and also Iva Kostešić for providing the information on the field research of the cistern. I would also like to thank all the participants in the research on the Stari grad Novigrad na Dobri (2009 - 2012) for their contribution in the creation of the documentation used in this article. Special thanks go to Tatjana Tkalčec (Institute of Archaeology) for her support in my water management research, as well as for her valuable guidelines concerning the topic of this article. Finally, I would like to thank the employees of the State Archives in Karlovac for their geniality and for allowing me to use the photographs of Stari grad Novigrad na Dobri. 


\section{KRATICE}

\section{ABBREVIATIONS}

HR-DAKA-0147: Zbirka fotografija i negativa, serija Objekti, košuljica Novigrad na Dobri (stari dvorac), inv. br. 7510.1. / Collection of photographs and negatives, set Objects, pouch Novigrad na Dobri (old castle), inventory no. 7510.1 .

\section{BIBLIOGRAFIJA BIBLIOGRAPHY}

Arnold 2008 - S. Arnold, Die hoch- bis spätmittelalterliche Burg der Hessonen in Wolfsölden (Gemeinde Affalterbach, Landkreis Ludwigsburg), in Arnold, S., Damminger, F., Gross, U., Mohn, C. (eds.), Stratigraphie und Gefüge, Beiträge zur Archäologie des Mittelalters und der Neuzeit und zur historischen Bauforschung, Festschrift für Hartmut Schäfer zum 65. Geburtstag, Forschungen und Berichte der Archäologie des Mittelalters in Baden-Württemberg 28, Landesamt für Denkmalpflege im Regierungspräsidium Stuttgart, Konrad Theiss Verlag, 2008, 67-79.

Bänteli 2009 - K. Bänteli, Wasserversorgung und Entsorgung im mittelalterlichen und neuzeitlichen Schauffhausen, Mitteilungen der Deutsche Gesellschaft für Archäologie des Mittelalters und der Neuzeit: Wasserbau in Mittelalter und Neuzeit 21, 2009, 161-172.

Bergant 1977 - T. Bergant, Stari grad nad Celjem: raziskovanja v letih 1973 in 1974. Poizkus rekonstrukcije rasti grajskega jedra, Filozofska fakulteta Univerza v Ljubljani, 1977

Delonga 1987 - V. Delonga, Staklo srednjovjekovnog Bribira, Starohrvatska prosvjeta 17, 1987, 87-110.

Дерменджиев 2006 - Е. Дерменджиев, Водохранилището на Царския дворец в столичния Търновград / The Cistern of the Royal Palace in the Capital City of Tarnovgrad, Археология 47/1-4, 2006, 201-210.

Großmann 2009 - U. G. Großmann, Gewöhnliche und ungewöhnliche Wege zur Wasserversorgung von Burgen, Mitteilungen der Deutschen Gesellschaft für archäologie des Mittelalters und der Neuzeit, Wasserbau in Mittelalter und Neuzeit 21, 2009, 181-188.

Gusar 2010 - K. Gusar, Kasnosrednjevjekovna i novovjekovna glazirana keramika na širem zadarskom području, unpublished PhD thesis, Sveučilište u Zadru, 2010

Holl 1955 - I. Holl, Külföldi kerámia Magyarorországon (XIII-XVI. század) / Ausländische Keramikfunde des XIII.-XVI. Jahrhunderts in Ungarn, Budapest Régiségei 16, 1955, 147-197.

Horvat 2012 - Z. Horvat, Oprema i pojedinosti na burgovima kontinentalne Hrvatske, Prostor 20/1(43), 2012, 2-19.

Houška, Mačković 2009 - M. Houška, R. Mačković, Srednjovjekovni Zelingrad, Kaj 42/6, 2009, 47-60.

Juch 2019 - S. Juch, Die Zeiselburg: Zur Sachkultur mittelalterlicher Burgen im Ostalpenraum am Übergang vom Hoch-zum Spätmittelalter, Geschichtsverein für Kärnten, 2019

Krömer 2019 - M. Krömer, Von der mittelalterichen Burg zur neuzeitlichen Befestigung, Die Hohenburg bei Homberg (Efze) in Hessen, Mitteilungen der Deutschen Gesellschaft für archäologie des Mittelalters und der Neuzeit, Befestigung und Grenze in Mittelalter und Neuerzeit 32, 2019, 165-178.

Kruhek 2003 - M. Kruhek, Novigrad na Dobri, Društvo prijatelja Novigrada na Dobri Frankopan, 2003

Lopašić 1895 - R. Lopašić, Oko Kupe i Korane, Matica Hrvatska, 1895.
Marinović 2019 - I. Marinović, Bunari i cisterne na srednjovjekovnim arheološkim nalazištima u kontinentalnoj Hrvatskoj, unpublished MA thesis, Filozofski fakultet u Zagrebu, 2019

Mihelić 2010 - S. Mihelić, Starigrad Novigrad na Dobri, Hrvatski arheološki godišnjak 6/1, 2009, 310-313.

Mihelić 2011 - S. Mihelić, Stari grad Novigrad na Dobri, Hrvatski arheološk godišnjak 7, 2010, 345-348.

Mihelić 2012 - S. Mihelić, Stari grad Novigrad na Dobri, Hrvatski arheološki godišnjak 8, 2011, 334-336.

Mihelić 2013 - S. Mihelić, Stari grad Novigrad na Dobri, Hrvatski arheološki godišnjak 9, 2012, 409-412.

Rhomberg $2001-\mathrm{H}$. Rhomberg, Die Wasserversorgung auf Burgen, Tätigkeitsbericht des Burgenausschusses des Vorarlberger Landesmuseumsvereins, 2001, 42-49.

Sekulić-Gvozdanović 1966 - S. Sekulić-Gvozdanović, Novigrad na Dobri, Bulletin za likovne umjetnosti Jugoslavenske akademije znanosti i umjetnosti 14/1-3, 1966, 27-39.

Stopar 1982 - I. Stopar, K problemu cisterne na gradu Celje, Varstvo spomenikov 24, 1982, 5-15

Šimek 2010 - M. Šimek, Srednjovjekovno staklo iz Varaždina, Archaeologia Adriatica 4/1, 2010, 307-324.

Škiljan 2015 - I. Škiljan, Srednjovjekovni i ranonovovjekovni pećnjaci Slavonije, unpublished PhD thesis, Filozofski fakultet u Zagrebu, 2015

Tkalčec 2010a - T. Tkalčec, Burg Vrbovec u Klenovcu Humskom: deset sezona arheoloških istraživanja, Muzeji hrvatskog Zagorja, Institut za arheologiju, 2010.

Tkalčec 2010b - T. Tkalčec, Kuhinjska i stolna keramika iz stambenog dijela burga Vrbovec u Klenovcu Humskom, Vjesnik arheološkog muzeja u Zagrebu $43,2010,455-476$

Tkalčec 2019 - T. Tkalčec, Nastavak arheoloških istraživanja cisterne i konzervatorskih radova unutrašnjosti kule burga Vrbovca u Klenovcu Humskom 2018. godine, Annales instituti Archaeologici 15, 2019, 145-152.

Vitalievna-Ginkut 2019 - N. Vitalievna-Ginkut, Italian Glazed Ware from the Genoese and Ottoman periods discovered in the consulate and fortress of Cembalo, Античная древность и средние века 47, 2019, 170-194.

Wasser auf Burgen im Mittelalter 2007 - Wasser auf Burgen im Mittelalter, Geschichte der Wasserversorgung 7, Frontinvs-Gesellschaft e. V., Landschaftsverband Rheinland, Rheinisches Amt für Bodendenkmalpflege, Verlag Philipp von Zabern, 2007.

Werner 1974 - M. Werner, Die Burgruine Alt-Wartburg im Kanton Aargau: Bericht über die Forschungen 1966/67, Schweizer Beiträge zur Kulturgeschichte und Archäologie des Mittelalters 1, Walter-Verlag, 1974. 

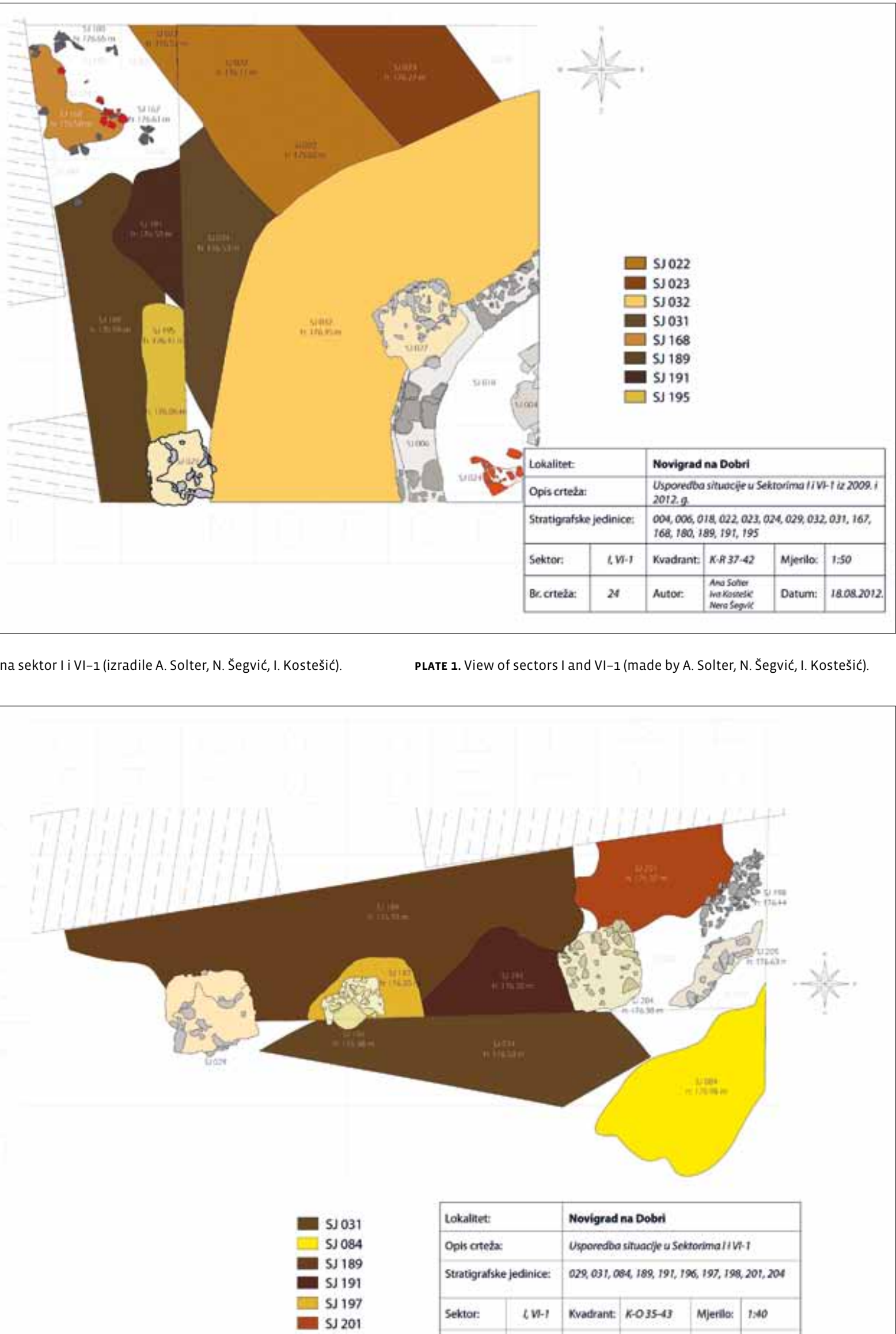

\begin{tabular}{|c|c|c|c|c|c|}
\hline \multicolumn{2}{|l|}{ Lokalitet: } & \multicolumn{4}{|c|}{ Novigrad na Dobei } \\
\hline \multicolumn{2}{|c|}{ Opis crtetx } & \multicolumn{4}{|c|}{ Usporedoa situacje u Sebtorimalivi-1 } \\
\hline \multicolumn{2}{|c|}{ Stratigrafske jedinice: } & \multicolumn{4}{|c|}{$029,031,054,189,191,196,197,194,201,204$} \\
\hline Sektor: & $\ell \mathrm{n}-1$ & Kvadrant: & $K-035-43$ & Mjerilo: & $1: 40$ \\
\hline Br. crteta & 28 & Autor: & Nend Segvic & Datum: & 24.08 .201 \\
\hline
\end{tabular}




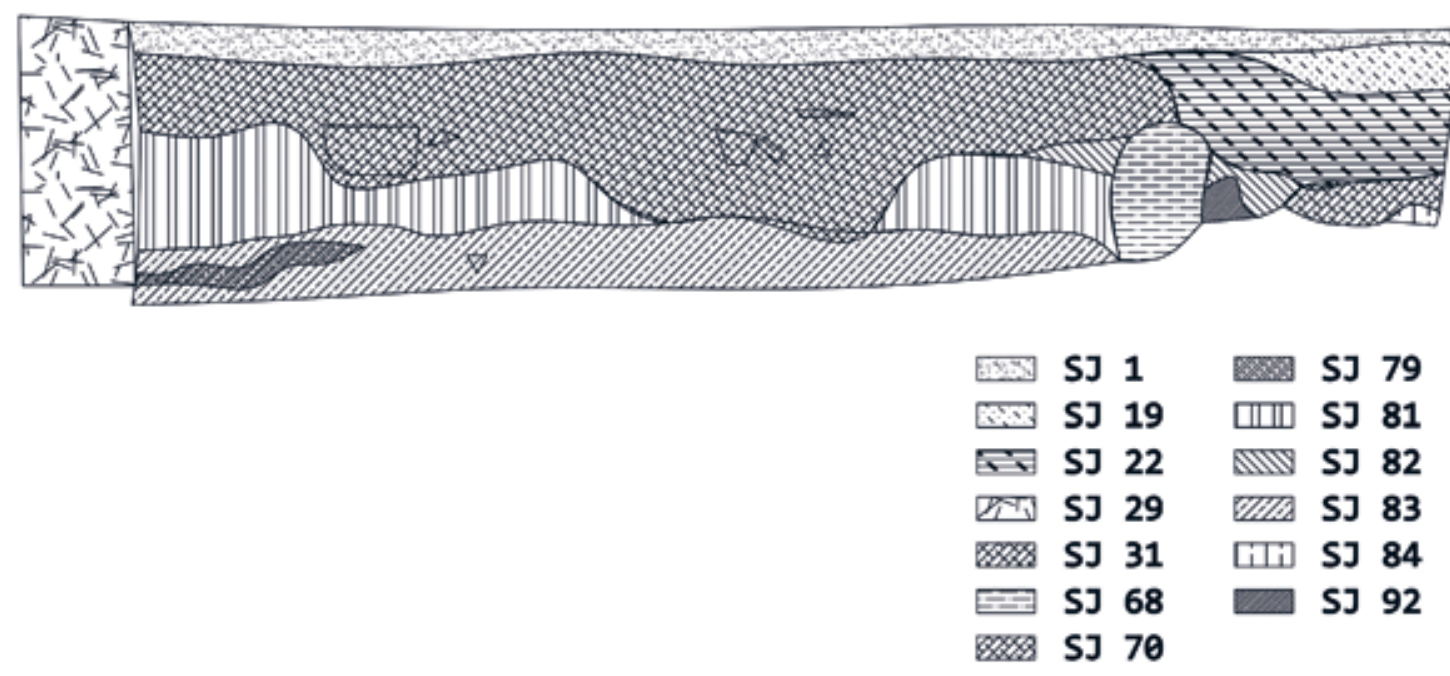

\begin{tabular}{|c|c|c|c|c|}
\hline Novigrad & & ri & & $\begin{array}{l}\text { Irtež } \\
\text { r. } 14\end{array}$ \\
\hline $\begin{array}{l}\text { Zapadn1 pr } \\
\text { sektora I }\end{array}$ & & $\begin{array}{l}\text { Sit } 1, \\
\text { m, } n \text {. }\end{array}$ & 2 & $n_{n, n}, \omega_{n}$ \\
\hline $\begin{array}{l}\text { Datua: } \\
\text { 15.es.2010. }\end{array}$ & & $1: 40$ & & Autor: \\
\hline
\end{tabular}

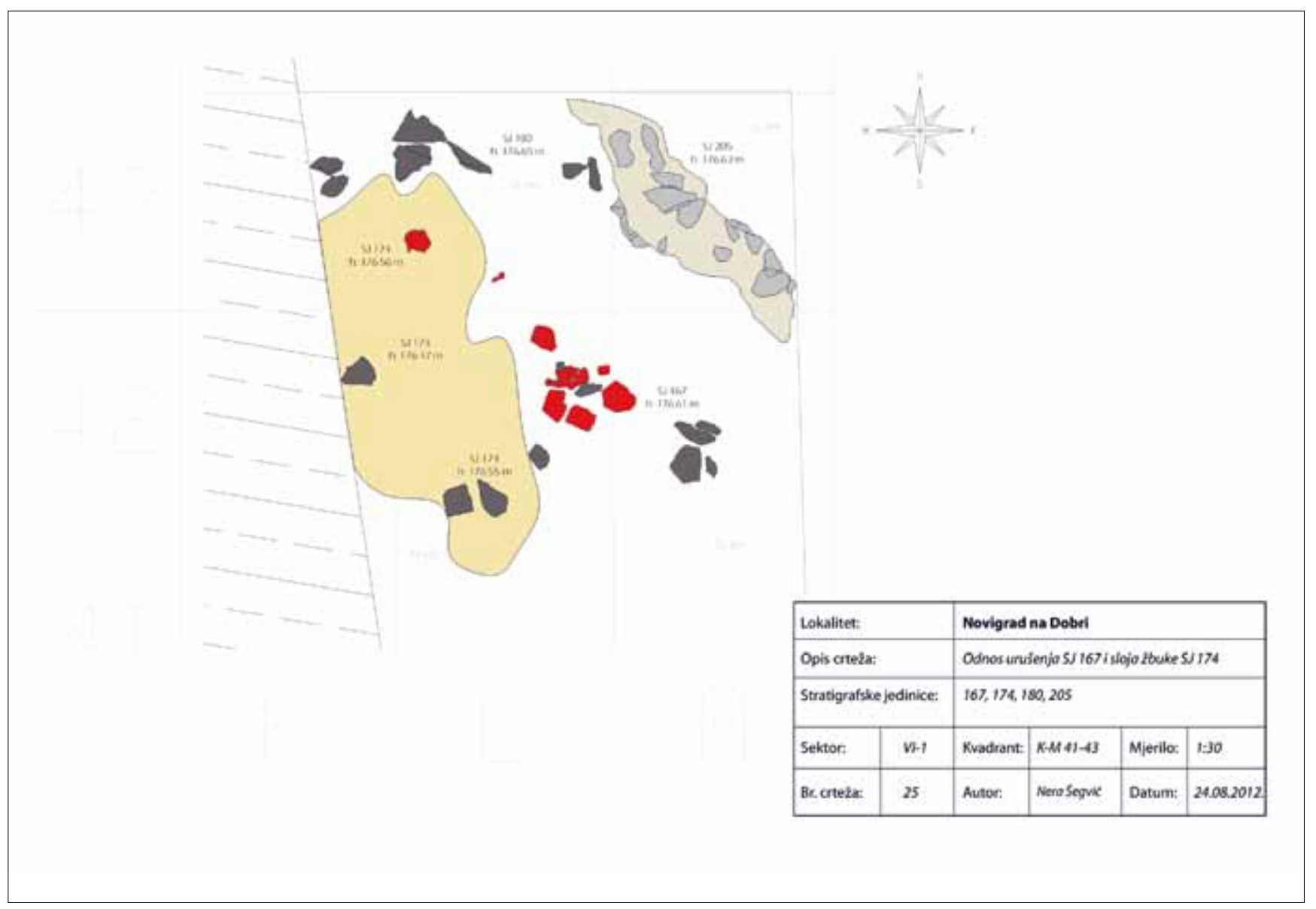



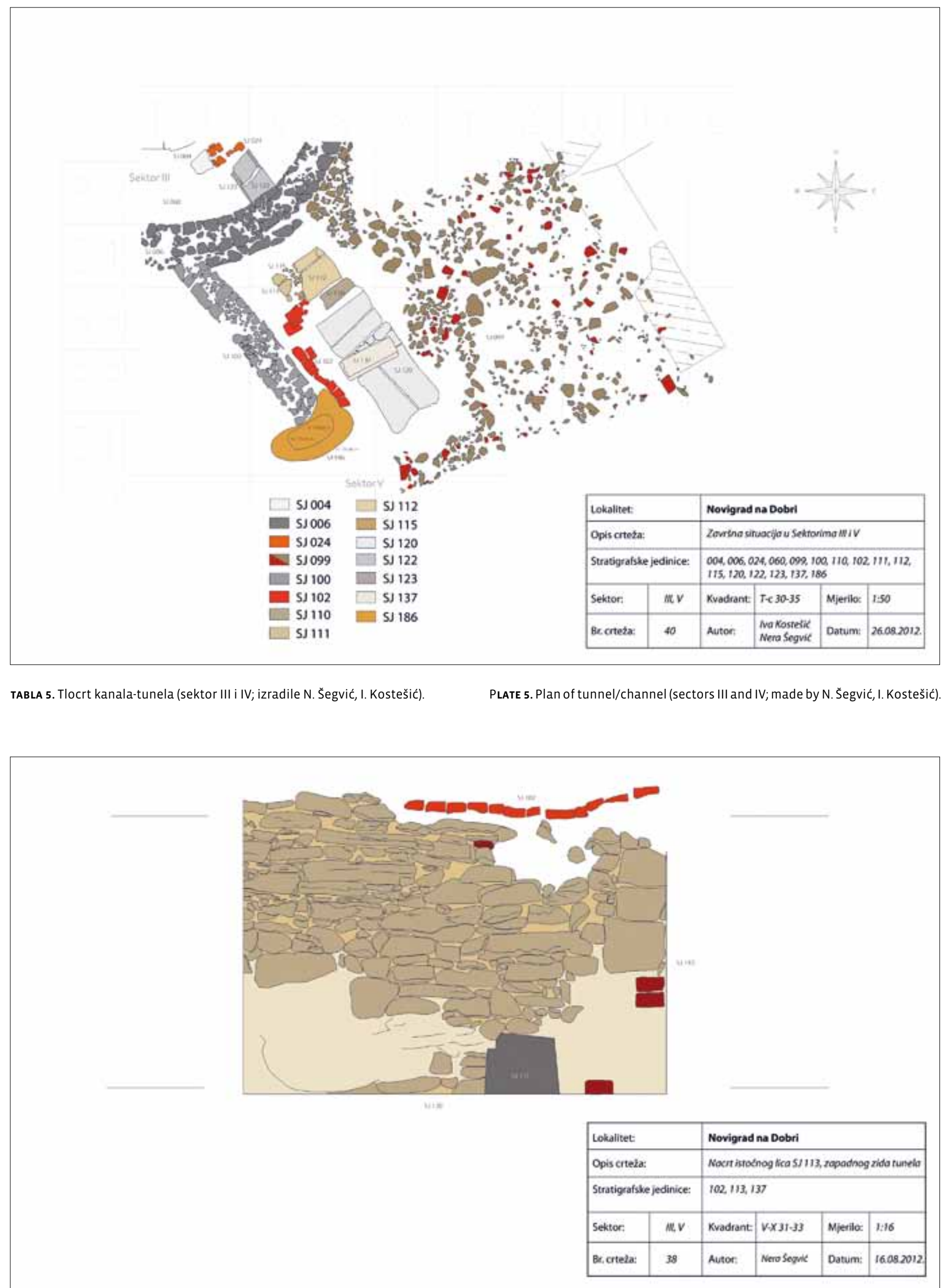